\title{
DVA LICA SPOMENIKA: POLITIKE I PRAKSE KORIŠTENJA SPOMENIKA SELJAČKOJ BUNI I MATIJI GUPCU U GORNJOJ STUBICI
}

TOMISLAV OROZ

Sveučilište u Zadru

Odjel za etnologiju i antropologiju

Dr. Franje Tuđmana 24i, 23000 Zadar

NEVENA ŠKRBIĆ ALEMPIJEVIĆ*

Filozofski fakultet Sveučilišta u Zagrebu

Odsjek za etnologiju i kulturnu antropologiju

Ivana Lučića 3, 10000 Zagreb
DOI: $10.17234 /$ SEC.27.4

Izvorni znanstveni rad

Primljeno: 1. 3. 2015.

Prihvaćeno: 6. 8. 2015.

Cilj je članka analizirati Spomenik Seljačkoj buni i Matiji Gupcu u Gornjoj Stubici kao materijalizirano sjećanje na prošlost konstruiranu u skladu s potrebama sadašnjosti. Spomeniku se pristupa iz perspektive ljudi koji ga na raznorodne načine koriste i oživljavaju, pri čemu je naglasak na njihovim kulturnim praksama u prostoru spomenika. Među nizom mogućih pogleda na Spomenik i izvedbe koje ga prate, autori se usmjeravaju na njegova dva lica, koja se odnose na dva povijesna trenutka, ali i dva različita modusa sjećanja. Jedno je povezano s kontekstom nastanka spomenika i njegovim komemorativnim i obljetničkim upotrebama u socijalizmu. Drugo lice dolazi do izražaja u 21. stoljeću kada se slike prošlosti utjelovljuju i uprizoruju u izvedbama oživljene povijesti.

Ključne riječi: Spomenik Seljačkoj buni i Matiji Gupcu u Gornjoj Stubici, Antun Augustinčić, socijalizam, Viteški turnir, Gubec teatar, društveno sjećanje

"Neka ovaj spomenik - monumentalno djelo našeg darovitog vajara Augustinčića - bude oličenje kontinuiteta borbe naših naroda za bolji život, za socijalnu pravdu i slobodu, i njihove vitalnosti u toj borbi. Neka sadašnju i buduće generacije opominje na zajedničke interese i sudbinsku povezanost naših naroda, na bratstvo i jedinstvo kao osnovnu garanciju njihovog života u slobodi i miru, i njihovog daljnjeg napretka." (Broz Tito 1975:[s. p.])

\footnotetext{
* Autorski prinos Nevene Škrbić Alempijević u ovome članku izrađen je u okviru projekta "Stvaranje grada: prostor, kultura, identitet" (voditeljica: dr. sc. Jasna Čapo Žmegač, broj: 2350), koji financira Hrvatska zaklada za znanost.
} 
"Gubec teatar je kombiniranom tehnikom animacije, filmskih sadržaja i svjetlosnih efekata oživio Spomenik Seljačkoj buni i Matiji Gupcu, a povijesna tema je na kreativan način povezana s bogatom retorikom umjetničkog djela dok je posebna novost 'oživljavanje' pojedinih likova na spomeniku koji se njime kreću u vrtlogu boje i pokreta, stalno podižući impresiju doživljaja. Kako je 21. stoljeće vrijeme procvata novih tehnologija pokazali smo kvalitetu novih dimenzija u povezivanju virtualnih rješenja, umjetničkih djela i javne memorije kojima se stvarni povijesni događaj pretvara $u$ multimedijalnu nacionalnu legendu."'1

\section{UVOD}

Spomenik Seljačkoj buni i Matiji Gupcu u Gornjoj Stubici u ovom radu promatramo kao materijalizirano sjećanje na odabrane povijesne epizode, junake i žrtve koji od vremena njegova planiranja šezdesetih godina prošlog stoljeća do danas opredmećuje i evocira postojeće te stvara nove predodžbe i naracije o prošlosti. Pristupamo mu kao žarištu raznolikih kulturnih praksi kojima se oživotvoruju dinamični dijalozi između prošlosti i sadašnjosti, u službi potvrđivanja, a ponekad i preispitivanja aktualnoga društvenog poretka (Connerton 2004:9). Pitanja koja pri istraživanju postavljamo su sljedeća: koji su motivi izmještanja povijesne ličnosti iz 16. stoljeća iz redaka povijesnih udžbenika u neposrednu i blisku svakodnevicu druge polovine 20. stoljeća? Što je uvjetovalo da Spomenik Seljačkoj buni i Matiji Gupcu postane nezaobilaznom referencijom u kulturnoj i turističkoj ponudi Hrvatskog zagorja, koja može parirati već ovjerenim mjestima okupljanja, hodočašća i putovanja poput Marije Bistrice ili političko-turističkim destinacijama kakva je Kumrovec? Navedena pitanja nastojat ćemo osvijetliti usmjeravanjem na konstrukciju i upotrebu Spomenika u Gornjoj Stubici kao vizualno dojmljivu i izvedbeno potentnu materijalizaciju slika prošlosti konstituiranih prema potrebama sadašnjosti.

Spomenik predstavlja naručenu umjetničku intervenciju u ruralnom krajoliku Hrvatskog zagorja te dio inventara Muzeja seljačkih buna, jedinice u sastavu Muzejā Hrvatskog zagorja, što omogućuje istraživačima

${ }^{1}$ http://www.msb.mhz.hr/html/projekti/teatar.html (pristup 10. 3. 2015.). 
da o njemu raspravljaju s aspekta kulturnih politika. No, istraživanjem društvene proizvodnje javnog prostora materijalizacijom sjećanja u njemu se ne iscrpljuju mogućnosti etnološke i kulturnoantropološke interpretacije spomenika, s obzirom na brojnost i heterogenost činova društvene konstrukcije spomenika, njegovih svakidašnjih reinterpretacija, korištenja i zamišljaja (usp. Low 2006). Stoga nam je cilj istodobno zahvatiti politike pamćenja i prakse/izvedbe sjećanja koje ovaj spomenik reflektira ali i generira. Pri takvoj analizi plodotvornom poveznicom među ovim sferama pokazuje nam se koncept prostora reprezentacije koji Henri Lefebvre određuje kao arenu u kojoj u prostor upisane slike i simboli oživljavaju doživljajima i postupcima njegovih različitih korisnika (1991:33). ${ }^{2}$ Zanima nas kako se i za koga povijest posredstvom spomenika konkretizira u prostoru, tvoreći u njemu "inscenaciju svakodnevice" (Rihtman-Auguštin 2000:16).

Premda već nekoliko desetljeća Gupčev lik raširenih ruku, okamenjenog i naizgled nepromijenjenog lica dočekuje posjetitelje dvorca Oršić u sklopu Muzeja seljačkih buna, raznolikost kulturnih praksi oživljenih podno Spomenika nikako se ne može svesti pod zajednički nazivnik. Iz množine različitih mogućih pogleda odlučili smo Spomenik detaljnije promotriti iz dvije vizure, predstaviti njegova dva društveno konstruirana lica: ono javno inaugurirano postavljanjem Spomenika 1973. godine te ono nanovo interpretirano mehanizmima oživljene povijesti, organiziranjem viteških turnira i drugih javnih događanja kojima Spomenik služi kao scena, od 2000. godine naovamo. Iako se ova dva modusa korištenja spomenika međusobno ne isključuju, naše inzistiranje na njihovu odvojenom predstavljaju ne reflektira samo dihotomiju službenih i javnih uporaba spomenika u dva različita razdoblja nego i vidljivost raznolikih praksi koje oživljavaju u neposrednoj blizini spomenika. Jedan od problema kojih se pritom dotičemo jest pitanje njegovih korištenja. Trebamo li umjetničko djelo Antuna Augustinčića u prvom redu promatrati kao spomenički objekt

2 Prostori reprezentacije čine, uz prostorne prakse i reprezentacije prostora, elemente Lefebvreove koncepcijske trijade kojom objašnjava društvenu određenost javnog prostora (1991:1-67). 
ili je prije riječ o sceni prilagođenoj raznorodnim izvedbama? Na potonji pristup upućuju nas već djelatnici Muzeja u čijem se fundusu Spomenik nalazi: "Spomenik danas funkcionira kao pozornica, ali to je zato što je on napravljen kao pozornica. Upravo je zamišljeno da se tamo različita događanja organiziraju. Spomenik ima razglas, [...] ima otraga prostore za presvlačenje. Tako da je to što se on danas upotrebljava kao pozornica u skladu s onim kako je prvotno zamišljen."3 Analizirajući predstavljačku funkciju Spomenika u socijalizmu i postsocijalizmu, temeljem istraživanja raznolikih praksi koje je odvijaju u njegovoj neposrednoj blizini, nastojat ćemo propitati odnos povijesnih narativa emaniranih s platoa Spomenika te njihovu recepciju i reprodukciju. Izvedbena dimenzija društvene dinamike koju Spomenik pokreće upućuje nas na teorijske postavke Ervinga Goffmana i njegovo problematiziranje dramatizacije svakidašnjih situacija. Na pitanje kako se predstavljamo u svakodnevnom životu Goffman nudi odgovor povlačeći analogiju između društvenih interakcija u svakodnevici i izvedbenih mehanizama u institucionalnom kazalištu, promatrajući društvene situacije kroz vizuru kazališne predstave i dramaturških principa te promišljajući kompleksnost društvenih uloga i nastupa kroz metaforu publike i izvođača (2000:10). U radu se bavimo predstavljačkom komponentom povezanom s licima Spomenika koja prikazujemo, pri čemu smo svjesni fluidnosti granica između publike i izvođača, na što upozorava i sam Goffman (ibid.).

Svoju analizu temeljimo na raznolikim metodološkim postupcima i na raznorodnoj građi koja je mogla osvijetliti suvremena korištenja Spomenika, ali i njegove prethodne namjene. Takva građa obuhvaća medijske izvještaje o svečanom predstavljanju Spomenika uoči četiristote obljetnice Seljačke bune, monografije i časopise objavljene u povodu obilježavanja, do raznolike vizualne građe koja nam je mogla približiti doživljaje spomenika u sedamdesetim godinama 20. stoljeća. Svjesni smo toga da ovakav dominantni diskurs koji je pratio nastanak Spomenika umnogome ostaje lišen heterogenih doživljaja, dojmova i praksi koji nisu u skladu s njegovom službenom namjenom. Neslužbene, individualne

3 Iz intervjua s Vlatkom Filipčić Maligec, muzejskom savjetnicom i aktualnom voditeljicom Muzeja seljačkih buna u Gornjoj Stubici, održanog 10. veljače 2015. godine. 
i varijabilne upotrebe Spomenika nerijetko su izmicale bilježenju u dostupnim izvorima, što je za cilj imalo stvaranje dojma o tome da je službeno, "monumentalno lice" spomenika ujedno i jedino moguće lice socijalističke vizure Seljačke bune te jedino vrijedno spomena. Otklanjajući se od teze o postojanju isključivo jednog, općeprihvaćenog lica Spomenika tijekom socijalizma, u prvom analitičkom dijelu ovoga članka upustit ćemo se $u$ analizu politike Spomenika dirigirane s vrha društvene hijerarhije.

Nadalje, razumijevanje njegovih suvremenih upotreba pokušali smo približiti kroz intervjue s nositeljima kulturnih politika vezanih uz Spomenik, praćenjem i sudjelovanjem u suvremenim događanjima poput Viteškog turnira u Gornjoj Stubici koji se odvija u blizini Spomenika, prezentaciji projekta Gubec teatra, te stručnoj i znanstvenoj literaturi posvećenoj Spomeniku koja problematizira njegove umjetničke, povijesne i memorijalne funkcije. Među mnoštvom današnjih reinterpretacija Gupčeva lika posredstvom Spomenika odlučili smo se za detaljnije istraživanje onih koje se definiraju sintagmom "oživljena povijest". ${ }^{4}$

\section{"MJESTO OKUPLJANJA, MJESTO NOVOG STVARANJA" - NASTAJANJE SPOMENIKA SELJAČKOJ BUNI I MATIJI GUPCU}

"Mi sada imamo spomenik Seljačkoj buni oko kojeg se dnevno okupljaju stotine ljudi iz svih krajeva naše zemlje. Kao što se nekad išlo na hodočašće u Mariju Bistricu, sada se to čini spomeniku u Stubici. Niti jedan spomenik u nas ne privlači toliko posjetilaca, a ta činjenica sama za sebe govori da spomenik izvršuje njemu namijenjenu funkciju." (Sabolić 1974:84-85)

\footnotetext{
${ }^{4}$ Pritom želimo naglasiti da dva lica Spomenika koja u članku osvjetljavamo nikako ne smatramo reprezentativnima, a još manje jedinima. Svaka od kulturnih praksi u dvama razdobljima relevantna je i vrijedna istraživačke pozornosti. Međutim, analiza koja bi obuhvatila svu množinu uočenih praksi, višestrukost značenja koje upisuju njihovi nositelji, prelazi okvire ovoga rada. Smatramo da i fokusiranjem na odabrana dva lica Spomenika pružamo uvid u neke od načina na koje ljudi u dva promatrana razdoblja oživotvoruju povijest u krajoliku.
} 
Cilj je ovog poglavlja uputiti na odnose prema prošlosti koji oživljavaju podizanjem Spomenika Seljačkoj buni i Matiji Gupcu, koje pratimo putem dostupnih izvora poput novinskih članaka, zapisa onodobnih politički i društveno angažiranih pojedinaca, prigodno izdanih monografija i stručnih časopisa. Kraj Drugoga svjetskog rata i uspostava socijalističkoga društveno-političkog uređenja označili su početak novog razdoblja u kojem su načini tumačenja i korištenja Gupčeve ličnosti uvelike određeni ideološkim svjetonazorom i političkim obratima u Socijalističkoj Federativnoj Republici Jugoslaviji. Od sporadičnih proglasa tijekom Drugoga svjetskog rata u kojima buntovnost Gupčeva lika poziva na odmetanje od vlasti i priključenje partizanskom pokretu (usp. Žanić 1998:315-320), do poslijeratne retorike koja primiruje njegov buntovni duh, aktiviranje simboličkog potencijala Seljačke bune i Matije Gupca prilagođavalo se potrebama vremena, mijenjajući svoju dinamiku, retoriku i adresata. Unatoč stvaranju dominantnog narativa o Gupčevoj buntovnosti koja je utrla put Narodnooslobodilačkom ratu i Titovoj povijesnoj veličini, politički diskurs o Gupcu tijekom gotovo polustoljetnog trajanja Socijalističke Federativne Republike Jugoslavije ne treba smatrati statičnim i okamenjenim. Lik Gupca u socijalizmu pokazuje se kao dinamičan, kompleksan i slojevit fenomen koji je mijenjao svoju konfiguraciju, prilagođavajući se novim kontekstima. Za razliku od ratnih pokliča Gupčeva imena, ${ }^{5} \mathrm{u}$ mirnodopskom kontekstu posezanje za revolucionarnim aspektom njegove naknadno ispisane biografije nije zazivalo "zveket oružja" nego poslijeratnu obnovu zemlje i izgradnju socijalističkih društvenih odnosa. Također, naglasak se u izgradnji adekvatnoga društvenog sjećanja prebacio s Matije Gupca na Seljačku bunu koja simbolizira snagu proletarijata. U diseminaciji ideoloških stečevina netom okončane "socijalističke revolucije" i "narodnog oslobođenja" provođenih

\footnotetext{
5 Primjer iz kojeg je vidljivo evociranje Gupčeve revolucionarnosti za vrijeme Drugoga svjetskog rata vidljiv je u Titovu obraćanju Hrvatima. Tito je evocirao sjećanje na Matiju Gupca "koji se u prošlosti borio za pravdu i slobodu” (Damjanović 1983:61), dok je partizanima dao naputak da prilikom prolaska kroz hrvatska sela "trebaju pjevati partizanske pjesme, a od njih osobito pjesmu o Matiji Gupcu, kako bi potaknula na buntovno raspoloženje i masovni fizički otpor hrvatskog seljaka i širokih radnih masa" (Jelić 1973:336).
} 
ovjerenim obrascima medijske propagande (Senjković 2008:59-60), topos Seljačke bune postaje prikladnom metaforom za vrijednosti poput slobode, bratstva i jedinstva. Primjerice, u govoru koji je Miroslav Krleža održao u Stubici 1951. godine, povijesni martirij jugoslavenskih naroda evociran je prisjećanjem na Seljačku bunu koja je, prema Krležinu tumačenju, odraz "volje za narodnom slobodom, socijalnom pravdom i za jednakošću" te "putokaz u historijskim tminama" (usp. 1975:[s. p.]). Njezinu važnost za suvremenost, usporedivu sa značenjem Francuske revolucije i socijalne revolucije pod vodstvom Josipa Broza Tita, Krleža dodatno naglašava dramatičnim opisom sudbonosne bitke, slikama svjetla i tame, dobra i zla, obespravljenog naroda i ozlojeđenih moćnika.

Ideje o dostojanstvenom obilježavanju spomena na Seljačku bunu i Matiju Gupca i u godinama koje slijede nailaze na plodno tlo, ali i na konkretne prijedloge podizanja njima posvećenih spomen-obilježja. ${ }^{6}$ Tako, primjerice, glasilo Glas Hrvatskog zagorja u članku pod naslovom Augustinčić i Zagorje od 29. listopada 1954. godine u prikazu života i djela najznamenitijega zagorskog kipara Antuna Augustinčića ističe njegovu posebnu povezanost s Hrvatskim zagorjem koja ga "zove i privlači”, koje mu govori "posebnim glasom djetinjih doživljaja i prvih uzbuđenja" (Krklec 1975:[s. p.]). Iako se odaje priznanje njegovu radu, napominjući kako još uvijek "brončano zvoni njegov spomenik Maršalu Titu u Kumrovcu", postavlja se pitanje njegova duga zavičaju u vidu spomenika jednom od najznamenitijih zagorskih sinova. "Postoji Stubica. Postoji stara lipa u selu ... I čim ga sretnem, prišapnut ću mu na uho, kako bi divno bilo da zamisli i da realizira još jedno djelo: spomenik Matiji Gupcu u njegovu rodnom mjestu." (ibid.). Odbor za proslavu 400-te obljetnice bune nastao je 1966. godine kao reakcija na Krležino

\footnotetext{
${ }^{6}$ Josip Mataić, jedan od članova Odbora za proslavu 400-te godišnjice bune, u zapisima o prvim idejama podizanja spomenika navodi već 1951. godinu kada je formiran prvi odbor za izgradnju spomenika. Ipak, u navedeno vrijeme on nije zaživio. Spomenici posvećeni Seljačkoj buni podignuti su već 1962. godine. Tako je, prema podacima koje iznosi aktualna voditeljica Muzeja seljačkih buna Vlatka Filipčić Maligec, iste godine podignuto spomen-obilježje na brdu Kapelščak, kao i spomen-ploča na kući podno Gupčeve lipe koju su podignuli planinari (2010:72).
} 
promišljanje o važnosti Seljačke bune i Matije Gupca u aktualnom političkom trenutku (usp. Vujčić 2013:3). ${ }^{7}$

"U historijskom ambijentu, kakav je posebno područje Stubice, i brda i doline, sela, zaseoci i mjesta odišu prošlošću" (Zdunić 1975:[s. p.]). Stajalište nositelja kulturnih politika u to doba bilo je da izgradnja spomenika u prostoru koji odiše prošlošću, kako ga opisuje Drago Zdunić, treba uvažavati ambijentalnost prostora, njegovu povijesnu komponentu ali i njegova fizička obilježja. Prvi pokušaji valorizacije prirodnog ambijenta na kojem je intervencija planirana ističu neuređenost i zapuštenost brda Samac u Gornjoj Stubici, što bi izgradnja spomenika trebala ispraviti. Nakon što je brdo očišćeno od bagremove šikare i zapuštenih vinograda, uočeni su prirodni i krajobrazni potencijali koji omogućuju skladno uklapanje spomenika u povijesnost prostora (Mataić 1975:[s. p.]). Tijekom osmišljavanja Spomenika unutar simbolički gusto premrežene povijesne pozornice mijenjali su se i dopunjavali odgovori na pitanje čemu sve Spomenik treba posvetiti te na koje sve načine sjećanje treba biti upisano $u$ prostor. ${ }^{8}$ Prvotni su planovi o spomenu na Seljačku bunu naknadno prošireni na izgradnju čitavog niza sadržaja, poput ceste nazvane Aleja lipa JNA koja povezivanjem Spomenika i dvorca Oršić čini "logičnu cjelinu autentičnog historijskog zbivanja" (ibid.). ${ }^{9}$ Zahtjev za poštivanjem ambijentalnih

7 Vlatka Filipčić Maligec u članku Crtice iz prapovijesti muzeja Seljačkih buna (iz hemeroteke Muzeja Seljačkih buna 1959.-1973. i dokumentacije o osnivanju Muzeja) kao godinu osnutka Odbora navodi 1963. godinu (2010:72), uz napomenu da Odbor u sastavu iz navedene godine nije zaživio. Monografija Matija Gubec izdana u povodu obljetnice, kao i publikacija Spomen na spomenik navode 1966. godinu kao godinu osnutka (usp. Zdunić 1975; Vujčić 2013:4).

${ }^{8}$ Tako su primjerice prvotne ideje o spomenu na Seljačku bunu isticale potrebu stvaranja spomenika Matiji Gupcu (usp. Krklec 1975:[s. p.]), tek naknadno spomenika Seljačkoj buni (Mataić 1975:[s. p.]), da bi nastankom Fonda za izgradnju spomenika započela institucionalna koordinacija na spomen-objektima i spomen-području (ibid.; Vujčić 2013).

${ }^{9}$ U godini svečanog obilježavanja Seljačke bune brojne su turističke agencije organizirale edukativne izlete u Gupčev zavičaj, a nerijetko su pobjednici školskih natjecanja iz povijesti osvajali nagradne izlete u Gupčev kraj (Mataić 1974:93). Novinski natpisi tako izvještavaju o akciji “Tragovima Zagorske i Gupčeve brigade” koja je uključivala obilazak povijesnih lokacija u Hrvatskom zagorju značajnih za razumijevanje povijesti NOB-a i Seljačke bune. Obilazak je završavao mimohodom učenika uzduž Aleje lipa JNA, te 
osobitosti posebno je došao do izražaja i temeljem zakonske odredbe Zakona o podizanju spomenika historijskim događajima i ličnostima koja je nalagala da se spomenici “organski uklope u neposredan život” (Vujčić 2013:5). Na tom je tragu i razmatranje Josipa Mataića, predsjednika Fonda za izgradnju spomen-objekata i proslavu 400-te godišnjice Seljačke bune, osnovanog 20. ožujka 1969. godine u Donjoj Stubici, koji nekoliko dana uoči svečanog predstavljanja Spomenika iznosi dojam kako "taj spomenik kao da već stotinama godina stoji na ovome mjestu” (Mataić 1975:[s. p.]).

Spomenik Seljačkoj buni i Matiji Gupcu svoje prve konceptualne konture zadobiva sredinom šezdesetih godina kada Antuna Augustinčića kontaktiraju članovi Odbora s molbom da osmisli idejno rješenje memorijalnog prostora. No, donošenje Zakona o podizanju spomenika historijskim događajima i ličnostima 1967. godine privremeno je osujetilo Augustinčićev rad na tom projektu. ${ }^{10}$ Naime, prema navedenom Zakonu izradi spomenika morao je prethoditi "opći jugoslavenski, anonimni natječaj” za spomenike arhitektonskog ili umjetničkog značaja. Jedna od propozicija natječaja bila je da se spomenik podigne ispod dvorca Oršić, popularno znanog kao Gupčev dom, pri čemu se ne smiju narušiti krajobrazne osobitosti. Preko osamdeset idejnih rješenja pristiglih na adresu ocjenjivačkog suda sastavljenog od renomiranih povjesničara umjetnosti, književnika, likovnih umjetnika, građevinara, urbanista i arhitekata, izazvalo je različite reakcije i nerijetko suprotstavljene vizije budućeg spomenika. "Razvijala su se mišljenja o skulptorskim

okupljanjem učenika pod Gupčevom lipom gdje su učenicima borci zagorske brigade "Matija Gubec" prepričavali svoja sjećanja na partizanske dane, upotpunjavajući ih referiranjem na Matiju Gupca (usp. N.R. 1972:7). "Upravo tu, pod tim stablom, i na ovom zagorskom tlu, gdje se gaji jedna tradicija dostajna junaka kao što je bio Matija Gubec i ideala za koje se borio. Kolonu mladića i djevojaka pod zastavama doveli su na ovo historijsko mjesto borci NOB-a, predsjednici boračkih organizacija Varaždina i Donje Stubice drugovi Franjo Žitnjak i Sukelj Fabijan da bi im ovdje rekli koju riječ ponosa na ono što je započeo Matija Gubec, a dovršio Josip Broz Tito u smislu onog što je na ovom mjestu prije dvadesetak godina napisao Miroslav Krleža: 'Naša životna volja danas, to je volja za socijalnom pravdom, jednakošću i ravnopravnošću i za narodnom slobodom, a to su bile parole pod kojima su pali Matija Gubec i njegovi stubički drugovi’." (ibid.).

10 Narodne novine, br. 1, god. XXIV, 12. siječnja 1968. 
traženjima novih formi i buntu spram konvencionalnog prikazivanja; raspravljalo se o teškoćama transformacije ideje u simbol, o namjeni i budućnosti spomenika, o usklađivanju spomenika s okolišem i dvorcem." (Vujčić 2013:6). Razmimoilaženje u stavovima članova ocjenjivačkog suda rezultiralo je time da je šest radova ušlo u uži izbor, iako su svi okarakterizirani kao predimenzionirani, idejno dvosmisleni ili nasilno apstraktni bez mogućnosti da se uklope u pitoreskni krajobraz pokraj dvorca Oršić (Filipčić Maligec 2010:74-78). ${ }^{11}$ Štoviše, i novinski natpisi koji su pratili polemiku između zagovornika i protivnika apstraktne vizije spomenika priklanjali su se kritici drugo nagrađenog rada Branka Ružića koji je novinara Večernjeg lista Vladu Novaka podsjećao na "mjesečeve module, reklame za šperploče ili Ferimport, faraonske grobnice" (ibid.). Za razliku od apstraktnih prijedloga, figurativna koncepcija spomenika kojoj je prethodno bio naklonjen Augustinčić bila je prihvatljivija članovima ocjenjivačkog suda. Nakon odluke o nedodjeljivanju prve nagrade, komisija je direktnom ad hoc nagodbom kontaktirala Antuna Augustinčića koji je prihvatio zadatak oblikovanja spomenika. Njegova je izrada trajala dvije godine i rezultirala je njegovim dovršetkom nekoliko dana uoči svečanog obilježavanja četiristote obljetnice 14. listopada 1973. godine. Augustinčić je Spomenik Seljačkoj buni i Matiji Gupcu zamislio kao "veliku pozornicu povijesnih zbivanja” (Mataić 1974:95), kao “panoramsku viziju života i patnje naroda", odnosno kao "mjesto okupljanja naroda, mjesto novog stvaranja” (Mataić 1975:[s. p.]). Stoga ga je osmislio kao otvorenu pozornicu urezanu u brijeg s kojeg se pruža otvoren pogled prema Donjoj Stubici. Spomeničku pozadinu čine dva krila dužine 20 metara i visine 7,5 metara. Lijevo krilo prikazuje Stubičku bitku, dok je desno krilo kolaž likova iz Krležinih Balada Petrice Kerempuha (usp. Vujčić 2013:10-12). Iskorak iz figurativne naracije spomeničkih krila čini figura Matije Gupca,

\footnotetext{
${ }^{11}$ Nakon završetka natječaja, svih osamdeset i šest radova pristiglih na natječaj izloženo je u Umjetničkom paviljonu. Rad br. 37 Branka Ružića koji je osvojio drugo mjesto, izazvao je najviše polemike među članovima komisije, ali i u medijskom prostoru. Tako primjerice u Večernjem listu članak Malo šale, malo zbilje - o spomenicima Seljačkoj buni, autor članka postavlja pitanje "što bi rekao jedan Zagorec da vidi legendarnu seljačku bunu kao tri uspravne toljage i niz složenih betonskih zidova?” (Filipčić Maligec 2010:78).
} 
ruku pruženih prema nebu, stisnutih pesnica, visine 6,5 metara, koju Gustav Krklec opisuje kao tragičnu figuru koja je ujedno i nevidljiva spona između dva svijeta prošlosti, odnosno "simbol narodnog vođe u davnim sukobima sa neodrživom stvarnošću” (Krklec 1975:[s. p.]). Liku Matije Gupca koji u središnjem dijelu platoa dominira Spomenikom kontrira figura Petrice Kerempuha, Krležina pučkog kroničara i zajedljivog promatrača stoljetnog tlačenja naroda. Svoje su mjesto unutar figurativne naracije Spomenika pronašli i suvremenici Augustinčićeva vremena, poput lika Miroslava Krleže ${ }^{12}$ smještenog na lijevom krilu Spomenika koji promatra Stubičku bitku, predsjednika Fonda Josipa Mataića, te Augustinčićeva suradnika kipara Vladimira Herljevića na desnom reljefu i Velibora Mačukatina. Impostacijom živućih osoba u reljefnu reprezentaciju povijesnog događaja i fantazmagoriju Balada Petrice Kerempuha, kao i izgradnjom platoa kojim je omogućen ulazak u prostor koji emanira povijesnošću, upućuje se na svevremenost Seljačke bune.

Svečano predstavljanje Spomenika u Gornjoj Stubici iz današnje se perspektive čini kao splet visoko stiliziranih i formaliziranih komemorativnih svečanosti. Novinski članci i prigodne publikacije poput monografija upotpunjuju sliku svečarskog raspoloženja, izvještavajući o pijetetu publike, zastavama jugoslavenskih republika i transparentima upućenima Titu i Gupcu. Opisi događanja na dan svečanog predstavljanja Spomenika ne samo da su egzaktni u detaljima protokola, pa čak i točno određenog vremena pojedinog događaja, nego i pridonose stvaranju osjećaja mističnosti koji obavija cjelokupno zbivanje. Tako se opisuje magla koja natkriljuje Spomenik, no koja se uoči Titova dolaska podiže otvarajući pogled iz Gupčeva doma prema krajoliku ispunjenom posjetiteljima. "Dolje u dolini, nešto jedinstveno: kroz maglu se pojavljuje more vozila, čitave su poljane prepune, sve ceste ispunjene autobusima, automobilima, na pruzi kompozicije vlakova, a ljudi još uvijek pritječu" (Mataić 1974:97). Iz toga mnoštva pristiže i kolona s Titom, kojeg dočekuju pripadnici JNA, omladina i omladinci u narodnim nošnjama. "Prepuno zborište izgleda poput košnice. Vijore se zastave, narod kliče, plješće drugu Predsjedniku i

${ }^{12}$ Krleža je smješten s lijeve strane kao promatrač povijesnih događaja. 
ostalim uzvanicima, svi su oduševljeni, a razdragani drug Tito vrlo je dobro raspoložen." (ibid.). Prožetost formaliziranog i performativnog jezika, na koju upozorava Paul Connerton (2004:86), a koja pridonosi stvaranju autentičnosti, nepatvorenosti i svetosti same Seljačke bune i Gupčeva lika, toga je dana posebno naglašena oživotvorujući figurativnu naraciju u pozadini događanja. Govori o Gupčevu liku i Seljačkoj buni te njezinu mjestu u povijesti NOB-a, ispaljivanje počasnih plotuna i svečana izvedba himne aklamiraju društveno prihvaćenu sliku narodnog heroja koji je pridonio razvoju socijalističke slobodarske narodne misli. Jakov Blažević, predsjednik Sabora SRH, u govoru kojim je upozorio na važnost Seljačke bune, Augustinčićevu je viziju bune okarakterizirao kao "spomenik koji će oživjeti historiju i povezati je sa socijalističkom sadašnjošću” (1974:[s. p.]), dok tadašnji zagrebački gradonačelnik Ivo Vrhovec u Spomeniku vidi sponu između ideala slobodarske prošlosti i socijalističke budućnosti (usp. Zdunić 1975:[s. p.]). Uoči Titova svečanog skidanja zastora sa Spomenika (slika 1), oglašavaju se zborovi pjevajući "puntarsku pjesmu 'Zdignite brati zastave, hej!"” (Mataić 1974:98). "U tom svečanom trenutku, općoj tišini mnoštva, čuje se snažna pjesma zbora, a zastavničari dižu zastave i polagano otkrivaju lik Matije Gupca" (ibid.). Da bi se ojačala povezanost Titove i Gupčeve ličnosti koji kontinuirano u opisima figuriraju kao "predvodnici masa u dva različita razdoblja [...] dva identična tipa čovjeka, dva revolucionara buntovnika protiv postojećeg stanja i ugnjetavanja" (Kovačić 1972:8), svečani čin obljetnice uveličan je i sadnjom nove lipe, no ovoga puta Titove. Prije stručnog vodstva po izložbenom postavu Muzeja seljačkih buna, na kojem se Tito prisjećao "detalja iz bune, pojedinih mjesta iz zavičaja gdje se buna odvijala, kao i narodnih običaja” (Mataić 1974:99), Tita dočekuje folklorni ansambl "Ivan Goran Kovačić" koji, izvodeći kolo, propušta druga Tita u prostor predviđen za sadnju lipe. Pri sadnji lipe kao simbola "bratstva i jedinstva, razvitka, napretka i mira naših naroda" (ibid. 98) pomažu mu seljaci u narodnim nošnjama legitimirajući time Titovu "ličnost koja je svim našim narodima uz Partiju ostvarila ideje što ih je u svijesti nosio Matija Gubec" (ibid. 100). Gupčeva lipa koju usmene predaje opisuju kao sastajalište pobunjenih kmetova (usp. Zečević 1969:12-13; Bonifačić Rožin 1966:15), te lipa posađena prilikom četiristote obljetnice, simbolički zaokružuju početak bune pod Gupčevim vodstvom i njezino dovršenje u Titove dane, transcendirajući specifičnosti prostora i vremena (usp. Halbwachs 1992:200). 


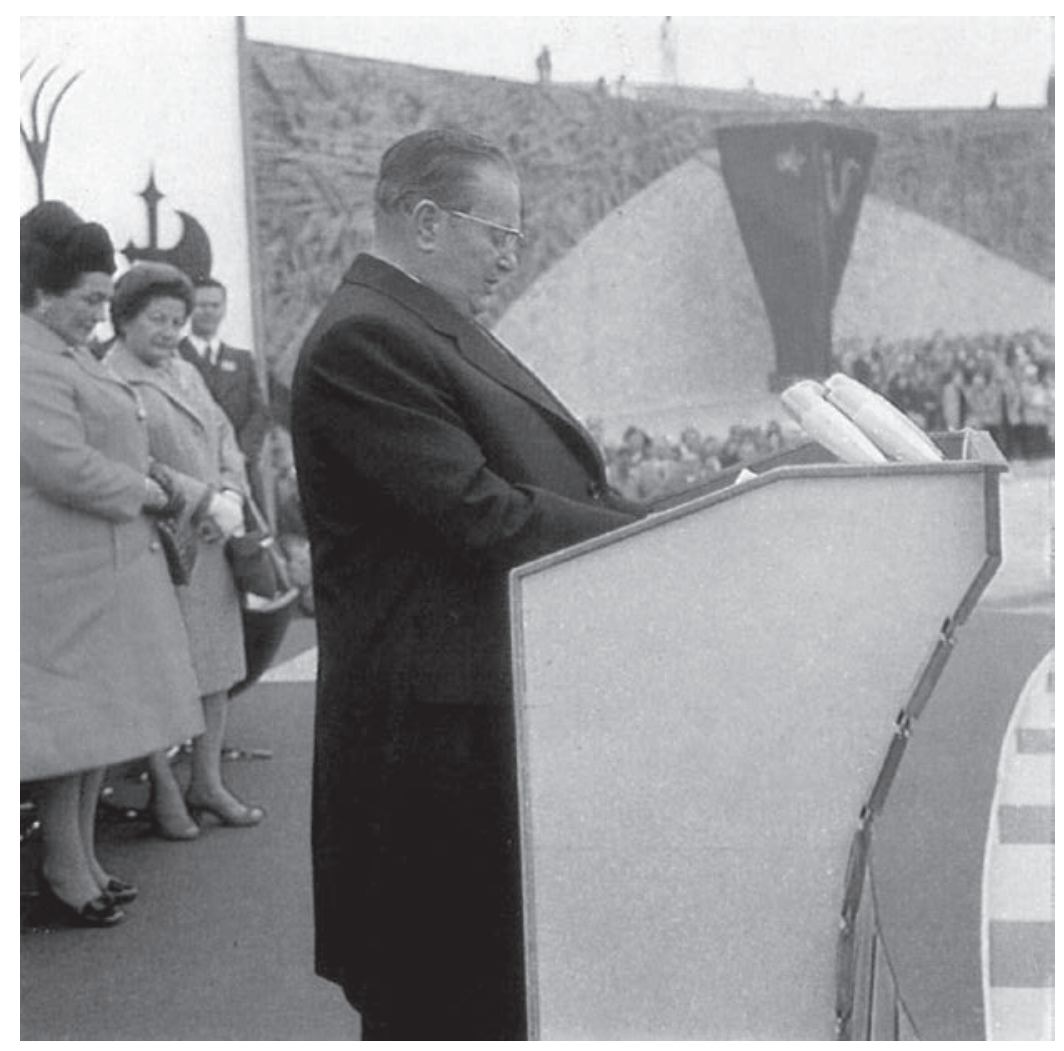

Slika 1: Josip Broz Tito uoči svečanog predstavljanja spomenika Seljačkoj buni i Matiji

Gupcu 14. 10. 1973. Izvor: Zdunić, Drago, ur. 1975. Matija Gubec: monografija o spomeniku Seljačkoj buni i Muzeju seljačkih buna u Gornjoj Stubici. Gornja Stubica: Muzej seljačkih buna, Zagreb: Spektar, str. 44

Spomenik je vrlo brzo postao odredištem školskih i sindikalnih izletnika, obiteljskih izleta, ali i posjeta političkih organizacija, nogometnih klubova i sl. Kao odraz "slobodarskog duha našeg vjekovima mučenog i potlačenog naroda" (Zdunić 1975:[s. p.]), u narednih nekoliko godina privukao je preko sedamdeset tisuća posjetitelja iz svih krajeva Jugoslavije, ali i šire: od Čehoslovačke, Italije, Rumunjske, SSSR-a, Njemačke, Bjelorusije, Francuske, SAD-a, preko različitih zemalja južne Amerike i Australije do Kine. Posjetitelji su pretežito bili naklonjeni Augustinčićevoj viziji Matije Gupca i Seljačke bune, o čemu svjedoči velik broj pozitivnih komentara u knjizi dojmova otvorenoj za javnost u povodu svečanog 
predstavljanja. Impresije posjetitelja u knjizi dojmova Spomenik predočuju kao "nešto najljepše što se može vidjeti kod nas" (ibid.), odnosno kao nešto "monumentalno", "veličanstveno", "funkcionalno", "nenametljivo", "izvanredno", pa čak i "autentično" (ibid.).

"U slobodarskoj zemlji i naš heroj Matija postaje slobodan" (ibid.), zaključuje jedan od posjetitelja, dok posjetiteljica iz Beograda zaključuje kako "prošlost, sadašnjost, budućnost živeće u nama kao trag meteora, [...] kao sećanje negdje u dubini u srcu o Matiji Gupcu." (ibid.)

Ideali Matije Gupca koji su ispred njegova vremena materijaliziraju se u spomeniku koji utopiju o ravnopravnosti čini opipljivom, upisanom u socijalističku svakodnevicu i u iskustvo posjetitelja.

\section{POVIJEST OŽIVLJENA U SUVREMENOSTI - UPOTREBE SPOMENIKA SELJAČKOJ BUNI I MATIJI GUPCU U 21. STOLJEĆU}

Devedesetih godina 20. stoljeća, u kontekstu uspostave samostalne Republike Hrvatske i Domovinskog rata, spomenička baština nastala u socijalizmu funkcionirala je kao jedna od brojnih platformi preoznačivanja nacije, konstruiranja adekvatnoga nacionalnog pamćenja kojim se legitimira uspostavljeno društveno uređenje (usp. Connerton 2004) te kolektivnog zaboravljanja nekih prethodno važećih "slavnih prošlosti", ponajprije onih vezanih uz Narodnooslobodilačku borbu i stvaranje Jugoslavije. Simboličkim poistovjećivanjem tih spomenika s agresorima i neprijateljima Hrvatske, mnogi od njih postaju nepoželjnim objektima. Stoga nerijetko nestaju iz javnih, posebno otvorenih prostora i izmiču se dosegu posjetitelja: sklanjaju se u zatvorena spremišta muzeja i galerija, u podrume javnih ustanova, zaboravljaju se u krajoliku i, nebrigom vlasti, postupno propadaju (Potkonjak i Pletenac 2011:13), a u nekim primjerima postaju metama vandalizma ili - kao što je slučaj s Augustinčićevim spomenikom Josipu Brozu Titu u Kumrovcu - raznošenja u zrak eksplozivnim napravama (Belaj 2006:201).

Spomenik Seljačkoj buni i Matiji Gupcu u tom razdoblju, a ni poslije, nije doživio intervencije u svoj fizički izgled ili smještaj u 
krajoliku. Nije izmijenjen ni njegov status spomenika kulture i muzejskog predmeta u fundusu Muzeja seljačkih buna koji 1992. godine ulazi u sastav Muzejā Hrvatskog zagorja. Spomenik i u postsocijalizmu figurira kao istaknuta turistička destinacija, pri čijoj se promidžbi redovito ističe kako je "[z]a većinu Hrvata naziv mjesta Gornja Stubica sinonim [...] za Matiju Gupca, vođu Seljačke bune iz 16. stoljeća". ${ }^{13}$ Spomenik pritom predstavlja neizostavnu postaju na kulturno-turističkim rutama koje apostrofiraju baštinu vezanu uz Seljačku bunu (primjerice, na kružnoj biciklističkoj stazi dugoj 35 km, nazvanoj “Gupčevim krajem”, zatim na planinarskom pohodu koji se organizira pod nazivom "Stazama Gupčevih puntara" itd.). ${ }^{14}$ Uz organizirane grupe koje se u Gornju Stubicu zapućuju posredstvom turističkih agencija, školske ekskurzije, skupine umirovljenika i različitih udruga te individualne posjetitelje, Spomenik je i dio političkog itinerara na lokalnoj, županijskoj i državnoj razini, pogotovo o obljetnicama Seljačke bune. ${ }^{15}$ Pritom se motiv Seljačke bune i lik Matije Gupca povezuju s konceptima ugrađenim u temelje njihovih političkih programa, doprinoseći time predodžbi o kontinuitetu i održivosti pojedinih političkih uvjerenja i načina društvenog djelovanja. Tako je, primjerice, tijekom svojeg posjeta Gornjoj Stubici 2013. godine, prilikom obilježavanja 440. obljetnice Seljačke bune, tadašnji predsjednik Ivo Josipović razlaganjem uloge Matije Gupca u hrvatskoj povijesti udahnuo povijesnost ideji pravde koju je isticao kao jedan od osnovnih ciljeva svoje politike: "Zagorje je dalo mnoge velike ličnosti, jedna od njih je i Matije Gubec. Toliko godina nakon bune divimo se tom čovjeku, jer je imao ideju pravde, a ona mora pokretati ljude i danas. Borit ćemo se za tu pravdu" (sp/VLM 2013). Na bliske se načine slike prošlosti vezane uz Seljačku bunu zazivaju na pozornici podno brda na kojem je Spomenik

13 http://www.zagreb-touristinfo.hr/istrazi-zagreb/zagreb-i-okolica/sjever (pristup 10. 3. 2015.).

14 http://www.tzzz.hr/biciklisticke-karte/karta-3/ (pristup 10. 3. 2015.); http://www.hpdkapela.hr/docs/stazama gupcevih puntara 07.01.2015.pdf (pristup 10. 3. 2015.).

15 Prema podacima Muzeja seljačkih buna, u drugoj polovini devedesetih godina Ministarstvo kulture Republike Hrvatske relativno je često dovodilo svoje ugledne posjetitelje u obilazak Spomenika. 
postavljen prilikom održavanja predizbornih skupova, tribina i drugih javnih događanja u organizaciji različitih političkih stranaka. ${ }^{16}$

Komponenta koja se u takvim prigodama jest promijenila, u odnosu na komemoracije i proslave koje su se oko Spomenika održavale tijekom socijalizma, jest adresat, odnosno pojedinci i skupine koji se simbolički nastoje predstaviti analognima davno izginulim sudionicima Seljačke bune, kao svojevrsni Matije Gupci našeg vremena. Stoga se iz naracija i praksi vezanih uz Spomenik brišu referencije na Tita i Narodnooslobodilačku borbu kao socijalističke pandane glavnom junaku i idealima Seljačke bune, a iz retorike se uklanjaju pojmovi poput bratstva $\mathrm{i}$ jedinstva, progresa $\mathrm{i}$ samoupravljanja. Takav je odmak od prethodnih memorijskih obrazaca odraz resemantizacije lika Matije Gupca i Seljačke bune primjetne u širem društvenom kontekstu. Ipak, imaginarij Seljačke bune i u samostalnoj Republici Hrvatskoj ostaje iznimno potentnim mjestom za upisivanje novih značenja i upućivanje na aktualne društvene potrebe. Akcije koje su u medijskom diskursu redovito opisivane aktualiziranjem aktera i motiva pobune iz 16. stoljeća predstavljaju seljački prosvjedi i blokade prometnica u sjevernom dijelu Republike Hrvatske od 2010. godine naovamo. Tako netom nakon početka organiziranih seljačkih prosvjeda književnik i kolumnist Mile Prpa u zaposjedanju zagorskih, podravskih i slavonskih cesta prepoznaje odjeke Gupčeve borbe za pravicu, u smislu demokratskog interveniranja obespravljenih u suviše stratificirano društvo:

"A Seljačka buna A.D. 2010 - bitka ista još uvijek se bije. Istina danas drugačijim sredstvima, traktorskim blokadama gradova, koje

\footnotetext{
16 Kako navode djelatnici Muzeja seljačkih buna, nedavno su na pozornici podno spomenika politička događanja organizirali predstavnici Hrvatske demokratske zajednice te Hrvatske seljačke stranke. No, ističu kako je pri korištenju ovog prostora vidljivo višestranačje, odnosno heterogenost pri iskazivanju raznorodnih političkih stremljenja i ideja (prema transkriptu intervjua s Vlatkom Filipčić Maligec, održanog 10. veljače 2015. godine). Drugim riječima, prostor oko spomenika simbolički ne zaposjeda samo jedna politička opcija niti se spomenik doživljava samo u jednom političkom ključu, što je slučaj s mjestima sjećanja drugih istaknutih povijesnih ličnosti koje se s Matijom Gupcem često povezuju u trojac "velikana Hrvatskog zagorja" - sa spomenicima i rodnim kućama Josipa Broza Tita i Franje Tuđmana (usp. Belaj i Škrbić Alempijević 2014; Škrbić Alempijević i Hjemdahl 2006).
} 
sve bliže i sve jače opkoljavaju grad Zagreb, hrvatsku političku i gospodarsku metropolu. Današnji [su] Tahiji harači, tajkunija, mafija, birokracija, rasprodaja hrvatskih nacionalnih vrijednosti, nebriga za Hrvatsku [...]. Takvoj [se] politici poniženja i obespravljenja svega hrvatskog, svega domoljubivog izgleda naslućuje otpor. Ali tko će biti naši novi Nikoli Kupinići, Josipi Thurni, Gašpari Alapići koji će rastjerati i 'poraziti' novovjeku seljačku 'vojsku', koja se skuplja sa svih strana u sve većem broju boreći se za stare pravice, a misleći poput njihovih slavnih predaka kmetova i boraca Matije Gubca, ne samo na stare pravice, već kako urediti Hrvatsku na podlozi rada, reda i pravednosti. Na podlozi dostojanstva, čovječnosti, domoljubnosti i hrabrosti." (Prpa 2010)

Iz autorova je komentara vidljivo da koncepti borbe protiv nadmoćnog neprijatelja zbog ideala, socijalne pravde, dostojanstva, slobode, mira i sl., sažeti u sintagmi Seljačke bune i utjelovljeni u liku Matije Gupca, i u postsocijalizmu predstavljaju plodotvornu podlogu za zamišljaj hrvatske sadašnjosti i kreiranje vizije bolje budućnosti zasnovane na predodžbi o junačkoj prošlosti našeg naroda. Daljnja kategorija koja se postavlja kao suvremeni baštinik Gupčevih stremljenja jesu hrvatski branitelji, sudionici Domovinskog rata, kako je naznačeno već u prethodnom citatu. Da aktualiziranje naslijeđa Seljačke bune predstavlja jednu od identifikacijskih strategija brojnih braniteljskih skupina govori i to da, prema riječima djelatnika Muzeja seljačkih buna, ${ }^{17}$ udruge branitelja iz Domovinskog rata u pravilu uključuju obilazak i fotografiranje pred Spomenikom u Gornjoj Stubici u svoj itinerar turističkih tura po Hrvatskom zagorju (usp. Gaši 2009).

Spomenutim upotrebama Spomenika u postsocijalizmu, koje su u prvom redu komemorativnog i obljetničkog tipa, osnovna je svrha inauguriranje nekih novih povijesnih istina koje se simbolički profiliraju kao opozicija socijalističkoj politici pamćenja, premda se strukturno konstituiraju istovjetnim elementima u funkciji stvaranja politike pamćenja. No, uz korpus protokolarnih postupaka i naracija u kojima se podrazumijeva postojanje monolitne nacionalne Povijesti, od

17 Prema transkriptu intervjua održanog 10. veljače 2015. godine. 
početka ovoga stoljeća uz Spomenik se također vezuju nešto opuštenije i heterogenije upotrebe povijesti, one koje se same definiraju sintagmama kreativnog preoblikovanja prošlosti, uključivanja što većeg broja sudionika u vlastito (re)kreiranje povijesnih zbivanja i ličnosti, njihovu oživljavanju kroz izvedbu. Riječ je o festivalima, performansima i drugim javnim događanjima koji su osmišljeni kao "portali u prošlost", kao arene u kojima se povijest uprizoruje ne samo u svrhu njezina boljeg poznavanja i razumijevanja nego kako bi je različiti sudionici doživjeli svim svojim osjetilima i ponovno učinili stvarnom svojim izvedbama (usp. Škrbić Alempijević 2012:185-212). Analiza takvih fenomena i procesa temelji se na osvrtu na dva javna događanja koja prostor neposredno oko Spomenika Seljačkoj buni i Matiji Gupcu, pa i površinu Spomenika, koriste kao mjesto izvedbe: na Gubec teatar, multimedijski $3 D$ video mapping izveden na samom Spomeniku 2013. godine, te na Viteški turnir koji se održava u Gornjoj Stubici od 2000. godine. Istraživanje tih događanja temeljimo na raznorodnim metodama i izvorima: na praćenju izvedbe Viteškog turnira 2014. godine, na intervjuima s organizatorima obaju događanja, na prezentaciji projekta Gubec teatar održanoj 1. prosinca 2014. godine u okviru manifestacije MUVI 05 Muzejskoga dokumentacijskog centra, zatim na analizi stručne literature posvećene ovim događanjima, medijskih osvrta, turističkih materijala, rasprava na internetskim forumima i sl. ${ }^{18}$

“'Gubec teatar'- multimedijalni 3D maping bio je dio obilježavanja jubileja. Cilj animacije bio je oživiti spomenik i multimedijalno prikazati seljačku bunu. Mnogi su likovi spomeničkog reljefa

\footnotetext{
18 Još jedno događanje kojim se izravno evociraju slike prošlosti vezane uz akcije i likove iz 16. stoljeća nosi naslov Seljačka buna 1593. To je višednevna manifestacija koja se održava krajem siječnja i početkom veljače u organizaciji Družbe vitezova Zlatnoga kaleža i Turističke zajednice Grada Donja Stubica na više lokaliteta u Donjoj i Gornjoj Stubici (rodna kuća Matije Gupca, Gupčeva lipa, predvorje Muzeja seljačkih buna, Majsecov mlin itd.). Riječ je o uprizorenju početka Seljačke bune u kojem sudjeluju izvođači odjeveni u rekonstrukcije onodobnih odora plemstva, vitezova i seljaka (usp. Lozančić 2009:58-68). No, budući da se nijedan od segmenata manifestacije ne odvija neposredno kod Spomenika i u komunikaciji s njime pa ni sama manifestacija ne služi kao platforma za njegovu reinterpretaciju, za razliku od dvaju događanja koja u članku analiziramo, nismo je uključili u obzor istraživanja.
} 
prohodali, letjeli ili jurnuli u bitku. Multimedijalni 3D mapping trajao je 15 minuta, a popraćen je glazbom i recitalom Vida Baloga koji je čitao ulomke djela 'Balada Petrice Kerempuha' Miroslava Krleže, zajedno s tekstom iz Habdelićevog prikaza Seljačke bune koji datira iz 17. stoljeća i izborom iz tzv. tužbe protiv Tahyja čiji se original iz 16. stoljeća čuva u Hrvatskom državnom arhivu. Zahtjevnom animacijom pojedinih prikaza na Spomeniku 'udahnuo' se novi život likovima". ${ }^{19}$

Ovako Novena d. o. o., profesionalni studio digitalnih medija, u suradnji s tvrtkom Pago Com d. o. o., specijaliziranom za tehničku izvedbu raznovrsnih događanja, opisuje multimedijski spektakl u čijoj je realizaciji sudjelovao. Gubec teatar je izveden jednokratno, 18. listopada 2013. godine, pred više od tisuću ljudi kao centralni dio proslave 40. godišnjice spomeničkog kompleksa i Muzeja u Gornjoj Stubici, te 440. obljetnice Seljačke bune, pod pokroviteljstvom tadašnjeg predsjednika Republike Hrvatske Ive Josipovića koji je događanju i nazočio te pred okupljenim uzvanicima održao prigodni govor o značenjima poruka Seljačke bune u današnjici. ${ }^{20}$ Muzej seljačkih buna je nositelj manifestacije, a muzejska savjetnica Goranka Horjan autorica je idejne koncepcije i scenarija. Kao motivaciju za organizaciju takvog događanja Horjan ističe da su "spomenik koji se već četrdeset godina nalazi pokraj Muzeja Seljačke bune željeli [...] prikazati i oživjeti na jedan novi način, koristeći jednu kombinaciju i novih tehnologija i izvedbenih umjetnosti". ${ }^{21}$ Gubec teatar izveden je tako kombinacijom animacije, pri kojoj su istaknutu ulogu imali likovi sa samog Spomenika, među ostalima Miroslav Krleža i njegov Petrica Kerempuh, zatim isječaka iz filma Seljačka buna 1573. Vatroslava Mimice i snimaka manifestacije "Seljačka buna 1573." u Donjoj i Gornjoj Stubici, te svjetlosnih efekata projiciranih na krila Spomenika. Kao literarni predlošci pri oblikovanju teksta također su korištena djela povezana $\mathrm{s}$

\footnotetext{
19 http://www.novena.hr/hr/novosti/gubec-teatar,140.html (pristup 10. 3. 2015.).

${ }^{20} \mathrm{https}: / /$ www.youtube.com/watch?v=7rJMILDMrJI (pristup 10. 3. 2015.).

21 Prema transkriptu prezentacije projekta koju je Goranka Horjan održala 1. prosinca 2014. godine u okviru događanja MUVI 05: muzeji-video-film, u organizaciji Muzejskoga dokumentacijskog centra.
} 
temom Seljačke bune, Krležine Balade Petrice Kerempuha i Prvi otca našeg Adama greh Jurja Habdelića, kao i navodi iz tužbi kmetova protiv Franje Tahyja u sudskom procesu. Popratna glazba koju je izvodio Ansambl za ranu glazbu Minstrel trebala je dočarati ozračje oživljenog vremena. Događanje funkcionira kao suvremena izvedbena reinterpretacija prošlih zbivanja koja na površinu Spomenika nanosi još jedan sloj značenja te mu pridaje nove mogućnosti iščitavanja i doživljavanja. Ipak, povijesna utemeljenost jedan je od koncepata za kojim realizatori projekta posežu kako bi još tješnje povezali ovo multimedijsko događanje s prostorom spomenika posvećenog Gupcu, čiji se lik u kontekstu projekta definira na sljedeći način: "Simbol je stoljetne borbe maloga čovjeka za pravicu i upravo zato smo odlučili uprizoriti priču o Buni i njezinom vođi sukladno novom vremenu". ${ }^{22}$ Time ova manifestacija pridaje dodatnu memorijsku, izvedbenu dimenziju Spomeniku kao mjestu sjećanja.

Oživljavanje, a ujedno i stvaranje sjećanja izvedbom srž je i sljedećeg događanja koje ćemo prikazati, Viteškog turnira u Gornjoj Stubici:

“Želeći privući posjetitelje u Muzej u što većem broju i pružiti im priliku da prošlost dožive na nov način, od 2000. godine posjetiteljima se u Muzeju seljačkih buna na jedan dan pruža prilika da iskorače iz užurbanosti 21. stoljeća i uđu u šaroliki svijet srednjega vijeka. To je dan kada se u Gornjoj Stubici organizira Viteški turnir. [...] Ideja Turnira bila je vraćanje na izmak srednjega vijeka, u polovicu 16 . stoljeća, i vrijeme prije velike Seljačke bune. Od početka svjesni da ponavljanje prošlosti nije moguće, pokušali smo uskladiti povijesnu istinu s našim mogućnostima prezentacije.” (Filipčić Maligec 2005:18).

Ovim riječima organizatori, predstavnici Muzeja seljačkih buna u Gornjoj Stubici, predočuju fenomen kojim se srednjovjekovna prošlost neposredno prije ustanka kmetova dovodi na suvremenu scenu. Istodobno, prošlost koja se oživljava festivalskim izvedbama i uprizorenjima nije jednosmjerna prošlost ponuđena posjetitelju kao pasivnom potrošaču. Naprotiv, ta prošlost uzemljena je u svakodnevicu, pri čemu je posjetiteljima

$22 \mathrm{http} / /$ www.novena.hr/hr/novosti/gubec-teatar---nagrada-simply-the-best, 143.html (pristup 10. 3. 2015.). 
omogućen ulazak u prostore njezina stvaranja. Viteški je turnir koncipiran kao segment šireg projekta naslovljenog Srednji vijek u Hrvatskom zagorju, kojim Muzeji Hrvatskog zagorja nastoje "udahnuti novi život" povijesnom naslijeđu te regije (Horjan 2009:430). Riječ je o jednodnevnoj kulturnoturističkoj manifestaciji koja se održava u lipnju, a u kojoj sudjeluje više stotina izvođača te više tisuća posjetitelja (ibid. 442). Cilj je ovog događanja pružiti posjetiteljima priliku za sudjelovanje u događaju "koji oživljuje odabrane epizode iz razdoblja kasnog srednjeg vijeka ili početka novog vijeka", odnosno pružanje doživljaja te prošlosti, običaja i života u tom razdoblju na inovativan način (ibid.). I premda organizatori Turnir vide kao platformu na kojoj se mogu predstaviti sve klase nekadašnjega feudalnog društva, ipak prevagu u zastupljenosti izvođača i brojnosti izvedbi u okviru programa, pa i u samom nazivu manifestacije, odnose vitezovi kao simbolički oponenti seljačkom sloju čije se junaštvo na tom lokalitetu, u Spomeniku, materijalizira (slika 2). Naime, okosnicu Turnira predstavljaju inscenirane borbe vitezova i nadmetanje kaskadera na konjima u različitim disciplinama kao što su sječa buča mačem, gađanje meta kopljem, nizanje obruča kopljem i sl., a koji se odvijaju na borilištu podno brda Samac i Spomenika (Filipčić Maligec 2005:19; Horjan 2009:434). Vitez je predstavljen kao središnja figura i u popratnim uprizorenjima, kao što su noćna opsada grada, odnosno dvorca Oršić, zatim podizanje vojnih logora brojnih, razlikovno kostimiranih, viteških družina koje nastupaju na turniru: Družbe vitezova zlatnog kaleža, ${ }^{23}$ Tahijevih puškara, Hrvatskog viteza, Vitezova zelingradskih itd. Riječ je o udrugama koje svoj program održavaju na brojnim manifestacijama i turnirima posvećenim srednjovjekovlju diljem Hrvatske, ali koji svoju izvedbu prilagođavaju lokalitetu na kojem se prošlost oživljava. O nastojanju da se općeprihvaćene predodžbe o srednjem vijeku povežu s određenim lokalnim specifičnostima govori kazivanje jednog od izvođača, voditelja Male škole glagoljice na Viteškom turniru 2011. godine:

23 Prema riječima djelatnika Muzeja seljačkih buna, osnivanje udruge dijelom je rezultat radionica i predavanja organiziranih u muzeju koje su s vremenom izašle iz okvira te ustanove, čime se pružila mogućnost slobodnijeg reinterpretiranja povijesti. Ipak, i danas se pojedini djelatnici muzeja aktivno uključuju u djelatnost Družbe vitezova zlatnog kaleža (prema transkriptu intervjua s Vlatkom Filipčić Maligec, održanog 10. veljače 2015. godine). 
"Gledajte, sve ove grupe tu, sve ove viteške udruge i mi koji radimo tu kraj borilišta, naravno, sve to spada u srednji vijek. Idemo do svih mjesta koji žele nešto od toga napraviti. [...] Neke druge velike zemlje od toga prave filmove, naprave biznis, a mi se tek uhodavamo i sretni smo kad netko uopće hoće nešto ovako napraviti. Ovo [Viteški turnir u Stubici] je ipak jedan događaj, jedan vanserijski događaj. Ove trupe viteške to rade zbog sebe, a opet oživljujemo dio povijesti onako ... kako koje mjesto u koje dođemo ima priču. To nisu možda neke bitke koje su bile bitne globalno, ali za lokalne ljude su bitne." ${ }^{24}$

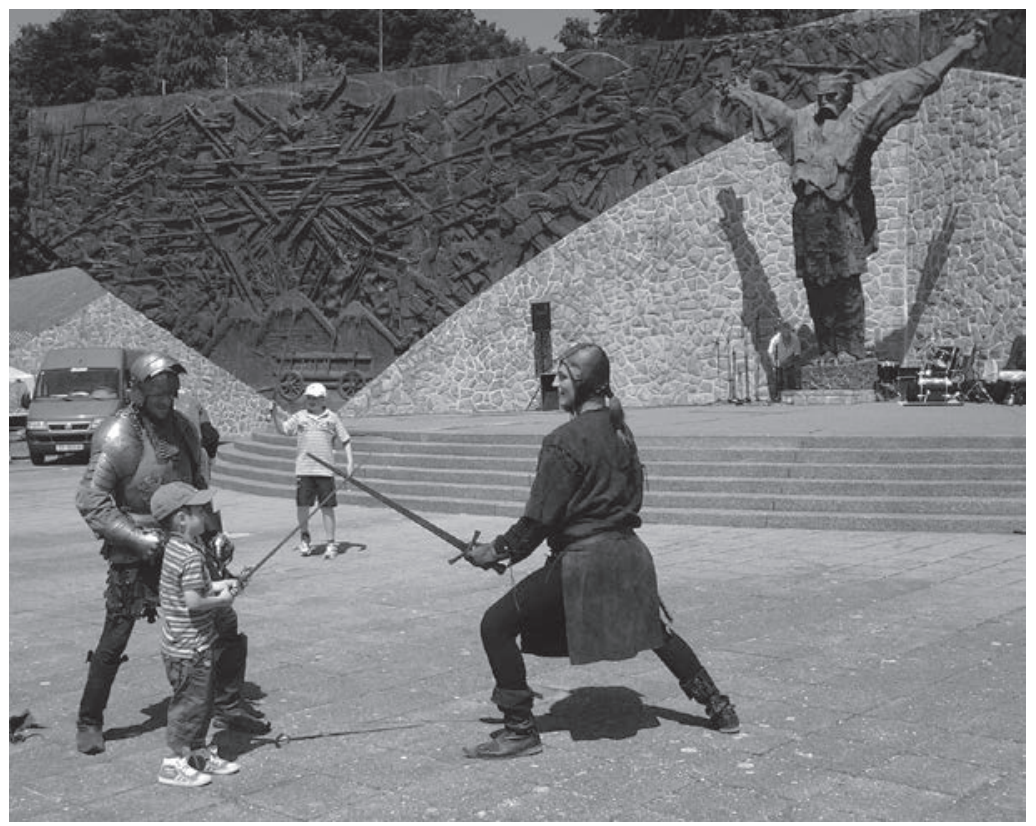

Slika 2: Sudionici Viteškog turnira u podnožju spomenika Seljačkoj buni i Matiji Gupcu u Gornjoj Stubici. Fotografirao Tomislav Oroz, 11. 6. 2011.

Viteške vještine poučavaju se u radionicama heraldike i baratanja srednjovjekovnim oružjem, kao i u okviru Dječjega viteškog turnira. Tzv. visoka kultura srednjovjekovlja promiče se također načinom odijevanja, kao i izvedbama srednjovjekovne i renesansne glazbe te dvorskih plesova.

24 Prema transkriptu intervjua s M. K., sudionikom Viteškog turnira, održanog 11. lipnja 2011. godine. 
Nadalje, viteštvo se proklamira kao povijesna i kulturna vrijednost prigodom otvorenja, pri kojoj izvođač koji glumi plemića - domaćina Turnira, ističe važnost Turnira za pripremu hrabrih vitezova "za višestoljetno vojevanje protiv Turaka pozivajući se na časti i dužnosti da brane svoju zemlju, svog zemaljskog gospodara i održavaju svetu katoličku vjeru i pravednost" (Horjan 2009:434). Pritom je viteška prošlost hrvatskog naroda i regije prošlost koja se na Turniru može iskusiti svim osjetilima: mirisima tradicijskih i srednjovjekovnih jela, zvucima srednjovjekovnog sajma, vrućini baklji gutača vatre i žonglera itd.

Neke od aktivnosti i segmenata Turnira odvijaju se u neposrednoj blizini Spomenika Seljačkoj buni i Matiji Gupcu, a i u interakciji s njime. Uz borilište podno brežuljka gdje se odvija nadmetanje konjanika, za turnirsko oživljavanje prošlosti koristi se i sam plato ispred Spomenika. Na toj se sceni, primjerice, odigravaju ceremonija otvorenja, smotra viteških družina, najave pojedinih događanja u okviru Turnira, na njoj se izvode dvorski plesovi i inscenirane borbe vitezova mačevima. U neposrednu okolicu spomeničke kompozicije postavlja se srednjovjekovni sajam koji Spomenik inkorporira u svoju festivalsku stvarnost. U svim tim momentima tijekom Turnira Spomenik ne figurira samo kao svojevrsna kulisa, kao reprezentativna scenografija za određeni vid oživljavanja povijesti. Njega se ujedno koristi kao pokazatelj da je povijest već upisana u taj prostor te otvorena za neka nova iščitavanja i doživljavanja. Podlogu za povezivanje Spomenika i Turnira predstavlja povijesna ravan na koju se obje materijalizacije sjećanja referiraju, slika o 16. stoljeću producirana u sadašnjosti, kako praksama vezanim uz Spomenik, tako i turnirskim izvedbama. Raskorak u tvorbi društvenog sjećanja u tim dvama kontekstima proizlazi iz pitanja čije se naslijeđe na tom mjestu aktualizira i veliča: ono vezano uz Seljačku bunu ili viteška prošlost?25 Toga su problema svjesni

25 Dodatan prilog rasvjetljivanju ovog pitanja predstavljala bi analiza predodžbi stanovnika Gornje Stubice o upotrebi motiva Seljačke bune i Matije Gupca u brendiranju njihova mjesta i o, po njihovu sudu, adekvatnim načinima na koje se to može postići. Međutim, takvo istraživanje prelazi okvire ovoga članka, koji je usmjeren ponajprije na analizu ovih javnih događanja kao mjesta tvorbe sjećanja na odabranu povijesnu epizodu i njezine junake. 
i organizatori, koji napominju da se Spomenik "ne uklapa baš sasvim u tu priču viteškog turnira”, ali pogled na srednjovjekovlje iz viteške vizure tumače očekivanjima i potrebama publike:

"Ljudi vole šarenilo, vole malo pompe, vole ipak da sve bude koncentrirano na malo više slojeve, oni, njihova odjeća i običaji su im zanimljiviji nego sami seljaci. [...] Kroz viteške turnire mi uvijek nastojimo pokazati i taj dio života seljaka. Međutim, figura seljaka na Turniru, nažalost, ne privlači toliko pažnje. Eto, seljaci se nisu borili na konju. Nisu imali tako raskošnu odjeću. Na kraju krajeva, nisu smjeli posjedovati mačeve niti drugo oružje prema Werbőczyjevim zakonicima, a sve to posjetitelji vole vidjeti na Turniru." ${ }^{26}$

Pobuđeni interes za srednjovjekovlje i vitešku kulturu primjetan je u Hrvatskoj od njezina osamostaljenja do danas (usp. Biti i Blagaić 2009), što je s jedne strane odraz trendova zamjetnih u festivalskoj industriji u čitavoj Europi, ali i novih strategija identifikacije na državnoj razini koje hrvatsko srednjovjekovlje tretiraju kao potentno mjesto simboličkog preutemeljenja nacije. Viteški turnir u Gornjoj Stubici uklapa se u taj trend. Na kraju, organizatori ističu da, premda Turnir ne predstavlja izravnu referenciju na Matiju Gupca i Seljačku bunu, izvođenje te manifestacije na njima posvećenom mjestu sjećanja ujedno dovodi do osvještavanja i dubljeg doživljavanja prošlosti koju Spomenik materijalizira. S obzirom na to da ovakve izvedbe i kulturne prakse, kao etnolozi i kulturni antropolozi, ne dijelimo na autentične, izvorne i povijesno utemeljene te one koje to nisu, nego svako takvo događanje promatramo kao mjesto stvaranja kulture (usp. Kelemen i Škrbić Alempijević 2012), oživljavanje sjećanja na vitešku prošlost shvaćamo kao još jedan korpus heterogenih kulturnih izvedbi koje korisnici ovog mjesta sjećanja generiraju.

26 Prema transkriptu intervjua s Vlatkom Filipčić Maligec, održanog 10. veljače 2015. godine. 


\section{ZAKLJUČAK}

Do kakvih nas zaključaka dovodi osvrt na dva lica Spomenika Seljačkoj buni i Matiji Gupcu u Gornjoj Stubici? Tematizirati dva lica Spomenika za nas znači usmjeriti se na raznolikost praksi pobuđenih u neposrednoj blizini Spomenika, namjena koje mu se pridaju i značenja koja se upisuju u njegovu pojavnost. Drugim riječima, više od samog Spomenika zanimala su nas njegova raznolika korištenja. U tom smislu povijesnu epizodu završenu prije više od četiri stoljeća promatramo kao podlogu za aktualne društvene i kulturne izvedbe, pri čemu nam se Spomenik otkriva kao prostor u kojem se isprepliću realno i fantastično, u kojem se ostvaruju dijalozi raznolikih istina, odnosno u kojem se ruše iluzije realističnog te stvaraju mogućnosti izvođenja alternativnih povijesti.

Pristup koji nam je omogućio da na istoj ravni promatramo i ophođenja u neposrednoj blizini Spomenika te predodžbe i iskustva koje on pobuđuje u socijalizmu i poigravanja imaginacijama prošlosti te alternativnih povijesti koje se performativno uprizoruju u postsocijalističkom kontekstu jest usmjeravanje na dinamiku oko Spomenika iz perspektive izvedbe, shvaćene slijedom Goffmanovih teza o tome da svaku društvenu interakciju u javnom prostoru možemo interpretirati kao način predstavljanja sebe drugima u svakodnevici (2000). Istodobno nam se Goffmanovo strukturiranje izvedbene situacije pojmovima kao što su "scena", "izvođači”, "nastupi" i sl., koji proizlaze iz analize međusobne komunikacije više ljudi, pokazuje preuskim za obuhvaćanje kompleksne i slojevite mreže odnosa koji se stvaraju između aktera u javnom prostoru, na mjestu sjećanja, u krajoliku ispunjenom poviješću. U našoj studiji, naime, Spomenik istodobno funkcionira i kao scena, i kao generator određenih evokacija prošlosti i izvedbi sjećanja, i kao adresat tih prisjećanja.

Govoreći o heterogenosti percepcija i djelovanja ljudi u interakciji sa Spomenikom, valja naglasiti da, za razliku od brojnih drugih povijesnih ličnosti proglašavanih narodnim herojima u socijalizmu, Gubec i u postsocijalizmu kotira kao nedvojbeno pozitivna ličnost te i dalje obilno ostvaruje svoj simbolički potencijal. No, bez obzira na kontinuitet takve valorizacije njegova lika i povijesne uloge, koncepti koji se uz Gupca vezuju te načini prisjećanja na njegovo djelo izrazito su varijabilni te ih možemo promatrati kao odraz vremena u kojima se prakticiraju. Naime, 
visoko stilizirane komemorativne prakse u podnožju Spomenika uoči njegova otvorenja koje oplakuju martirij poraženog seljaštva i Gupčeve nadvremenske ideale slobode i jednakosti, bitno se razlikuju od onih koje se uz Spomenik vezuju od početka ovoga stoljeća nadalje, kada se oko njega scenografski evocira romantizirano srednjovjekovlje s insceniranim bitkama kostimiranih vitezova i radionicama za najmlađe. U prvom se slučaju plato spomeničkog kompleksa ponajprije definira kao arena strogo formaliziranih državnih svečanosti koje, bez obzira na čvrstu komemorativnu strukturu, svojom otvorenošću za javnost stvaraju mogućnost za višestruka, usporedna čitanja i upotrebe motiva vezanih uz Seljačku bunu. U slučaju suvremenih manifestacija, Spomenik se hotimice transformira $u$ prostor na kojem prošlost oživljava izvedbama koje ne trebaju biti posve vjerne svom povijesnom modelu. Dok su u prvom analiziranom slučaju bratstvo i jedinstvo ključne vrijednosti koje se nastoje oprimjeriti Seljačkom bunom, u ovom se stoljeću primat daje kreativnosti i individualnosti kao odrednicama suvremenog građanina koji se prošlosti sjeća, ali na svoj način. Pritom ideali poput socijalne pravde (barem u retorici pojedinih političkih aktera) te žrtve naroda/puka za slobodu i mir predstavljaju podudarna mjesta pri koncipiranju politike pamćenja vezanih uz Spomenik u obama promatranim kontekstima.

Dva lica Spomenika Matiji Gupcu i Seljačkoj buni na koja naslovom upućujemo ne impliciraju prije svega dva različita razdoblja. Svjesni smo toga da bi se i u socijalizmu našlo primjera koji upućuju na opuštenija čitanja i doživljavanja povijesti potaknuta Spomenikom. Također, u postsocijalističkoj eri festivalskih izvedbi ili multimedijskih performansa u Hrvatskoj svečani, komemorativni karakter ophođenja prema Spomeniku, uz intoniranje državnih himni i održavanje svečanih govora, nikako nije dokinut. Stoga dvije studije koje smo predstavili shvaćamo prije kao okvire unutar kojih promišljamo disperznost raznolikih sjećanja i kreiranja prošlosti, ne odričući postojanje drugačijih praksi na tom lokalitetu, kao ni međusobno isprepletanje, međuprožimanje i međuuvjetovanost percepcija i aktualizacija Spomenika u različitim povijesnim epizodama. U tom smislu dva lica Spomenika, ono "monumentalno" u kojem se ogleda slavna povijest naroda, te ono "oživljeno" u kojem su moguća drugačija, kreativna uprizorenja minulih događaja, označavaju točku preplitanja različitih imaginacija prošlosti, predodžbi sadašnjosti i vizija budućnosti. 


\title{
TWO FACES OF THE MONUMENT: POLITICS AND PRACTICES IN THE USAGES OF THE MONUMENT TO THE PEASANT REVOLT AND MATIJA GUBEC IN GORNJA STUBICA
}

\author{
(Translation)
}

TOMISLAV OROZ

University of Zadar

Department of Ethnology and Anthropology

Dr. Franje Tuđmana 24i, 23000 Zadar

NEVENA ŠKRBIĆ ALEMPIJEVIĆ**

University of Zagreb

Faculty of Humanities and Social Sciences

Department of Ethnology and Cultural Anthropology

Ivana Lučića 3, 10000 Zagreb
DOI: $10.17234 /$ SEC.27.4

Original scientific paper

Received: 1 March 2015

Accepted: 6 August 2015

The aim of the paper is to analyze the Monument to the Peasant Revolt and Matija Gubec in Gornja Stubica as materialised memory of the past constructed in relation to present-day circumstances. The monument is approached through the prism of people who use it and bring it to life in diverse ways, with the emphasis on their cultural practices and performances in the memorial space. Out of a number of potential approaches to the Monument, the authors focus on its two faces, related to two historical moments, but also two different modes of memory. One is connected with the construction of the monument and its commemorative and anniversary usages in socialism. The other is created in the 21st century, when images of the past also become embodied in living history performances.

Keywords: Monument to the Peasant Revolt and Matija Gubec in Gornja Stubica, Antun Augustinčić, socialism, Chivalry Tournament, Gubec Theatre, social memory

"May this monument - a monumental work by our talented sculptor Augustinčić - be an embodiment of the continuity of our peoples' struggle for a better life, social justice and freedom, and their vitality in that struggle. May it stand as a reminder to the present and future generations of the common interests and the destined interconnectedness of our peoples, of the brotherhood and unity as

* The contribution by Nevena Škrbić Alempijević was a part of the project City-making: space, culture and identity (project leader: Jasna Čapo Žmegač, PhD, no.: 2350), financed by the Croatian Science Foundation 
the fundamental guarantee of their living in freedom and peace and their continued progress." (Broz Tito 1975:[s.p.])

"Gubec theatre used the combined techniques of animation, film and light effects to bring the Monument to the Peasant Revolt and Matija Gubec to life. It connected a historical theme with ample rhetoric of an art work in a creative way. A special novelty was the way in which some of the characters were 'animated' on the monument itself so that they moved in a whirl of colours and shapes thereby constantly intensifying the experience. As the 21st century is the period of flourishing new technologies, we have shown how new dimensions contributed to connecting virtual solutions, works of art and public memory and in this manner transformed a real historical event into a multimedia national legend."

\section{INTRODUCTION}

The paper views the Monument to the Peasant Revolt and Matija Gubec in Gornja Stubica as the materialised memory of selected episodes from history, namely heroes and victims, which has been objectifying and evoking the existing imagery and narrations about the past from its inception in the 1960s until today. We approach it as a focal point of diverse cultural practices which bring to life dynamic dialogues between past and present in order to legitimate, and sometimes re-examine a present social order (Connerton 1989:3). In research we ask the following questions: what are the motives for taking a historical figure from the 16th century out of the pages of history text-books and relocating it in the immediate and imminent present day of the second half of the 20th century? What caused the Monument to the Peasant Revolt and Matija Gubec to become an obligatory reference in culture and tourism supply of Croatian Zagorje which puts it shoulder to shoulder with already trusted places of gathering and pilgrimage like Marija Bistrica or political tourism destinations like Kumrovec? We shall try to shed

\footnotetext{
1 http://www.msb.mhz.hr/html/projekti/teatar.html (accessed 10/3/2015)
} 
light on the above mentioned questions by focusing on constructing and using the Monument in Gornja Stubica as a materialisation of the images of the past, which have performative potential and which are created in accordance with the present day needs.

The Monument itself represents an artistic intervention in a rural landscape of Croatian Zagorje and is a part of the Peasant Revolt Museum inventory, one of the sections of the Croatian Zagorje Museum. Therefore, researchers can discuss it from the standpoint of cultural policy. However, researching the social production of public space by way of materialised memory in it does not exhaust the possibilities of monument interpretation in ethnology and cultural anthropology, bearing in mind the numerous and heterogeneous instances of monument social construction, its everyday reinterpretations, usage and imagination (cf. Low and Lawrence-Zúñiga 2003). As a result, it is our goal to simultaneously cover the politics of remembering and the practices/materialised memory that this monument reflects and at the same time generates. In such an analysis a fruitful link between these spheres reveals a concept of representational space, which Henri Lefebvre designates as the arena in which images and complex symbolisms embodied in space are brought to life through experiences and actions of its various users (1991:33). ${ }^{2}$ We are interested to see how and for whose benefit history had been concretised in space by means of a monument, thereby creating in it the "enacting of the everyday" (RihtmanAuguštin 2000:16).

Although the statue of Gubec with open arms with a petrified and seemingly unchanged face had been greeting the visitors to the Oršić Palace, a part of the Peasant Revolt Museum, for several decades, the diversity of cultural practices enacted at the foot of the Monument could by no means be reduced to the lowest common denominator. Out of a multitude of different possible views, we chose two from which to observe the Monument in more detail. We wish to present its two socially constructed faces: a public

2 Representational space, together with spatial practices and representations of space, constitute the elements of Lefebvre's concept triad through which he explains the social definition of public space (1991:1-67). 
one, inaugurated on the occasion of putting up the Monument in 1973 and a newly interpreted one through mechanisms of revitalizing history by organizing Chivalry Tournaments and other public events to which the Monument has been a backdrop since 2000. Although these two ways of using the monument are not mutually exclusive, we insist on their separate representation. Not only does this reflect the dichotomy of official and public use of monuments in two different periods, but it also increases the visibility of diverse practices which are re-enacted in the immediate vicinity of the monument. One of the problems that we touch upon is the question of its usage. Should we perceive Antun Augustinčić's work primarily as a monument or is it rather to be viewed as a backdrop to be adapted to various performances? The latter approach has been referred to us by the staff of the Museum that the monument belongs to: "Today the monument is used as a stage, but it is because it was constructed as one. It was designed so that different events can be organised there. The monument has a PA system, (...) there are changing rooms behind it. The fact that it is used as a stage today is in accordance with its original design". ${ }^{3}$ By analyzing the performative function of the Monument in the socialist and post-socialist period, based on the research of diverse practices that take place in its immediate vicinity, we shall try to examine the relationship between historical narratives which emanate from the Monument's dais and their reception and reproduction. The performative dimension of the social dynamics that is instigated by the Monument refers us to Erving Goffman's theoretical hypotheses and the way he problematizes dramatizations of everyday situations. When asked about how we present ourselves in everyday life, Goffman offers a reply by making an analogy between social interactions in everyday life and mechanisms of performance in the institutional theatre. He observes social situations through the prism of a theatre play and considers the complexity of social roles and performances through a metaphor about audience and performers (1956:8-9). In the paper we look at the presentational component in connection to both faces of the Monument which we are presenting. In doing so we are aware of the fluid boundary between the audience and the performers that Goffman warns about (ibid.).

${ }^{3}$ From the interview with Vlatka Filipčić Maligec, museum consultant and current director of the Peasant Revolt Museum in Gornja Stubica, conducted on 10 February 2015. 
We are basing our analysis on diverse methodological procedures and various materials which could shed light on the Monument's contemporary as well as its past usage. Such materials encompass media reports on the occasion of the Monument's ceremonial unveiling on the eve of the Peasant Revolt quadricentennial; monographs and magazines published to mark the celebration; different visual materials that could explain how the Monument was experienced in the 1970s. We are aware that such a dominant discourse, which followed the creation of the Monument, in many ways remains devoid of heterogeneous experiences, impressions and practices that are not in line with its official purpose. Unofficial, individual and variable uses of the Monument often went unrecorded in the available source. The aim was to create an impression that the official, "monumental" face of the monument was at the same time the only possible face of the socialist views of the Peasant Revolt and therefore the only one worth mentioning. Wishing to distance ourselves from the thesis that there could only be one, generally accepted face of the Monument during the socialist period, in the first part of the paper we shall give an analysis of the Monument policy which was orchestrated by those on top of the social hierarchy.

Furthermore, we tried to make the understanding of its contemporary needs easier through interviews with those who implement the policy concerning the Monument by observing and participating in contemporary events like the Chivalry Tournament in Gornja Stubica, which takes place in the vicinity of the Monument, Gubec Theatre project presentation and by means of professional and scientific papers on the Monument that problematize its artistic, historical and commemorative functions. Among the many present day reinterpretations of Gubec's figure by means of the Monument, we chose to do a more detailed research of those reinterpretations that are encompassed by the phrase "re-enactment of history". ${ }^{4}$

\footnotetext{
${ }^{4}$ We would like to stress that the two faces of the Monument, which we are elucidating in the paper, are by no means considered representational or indeed the only ones. Each of the cultural practices in the two time periods is relevant and worthy of attention and research. However, an analysis which would comprise the overall multitude of perceived practices and the complexity of meaning that are attributed to it goes beyond the scope of this paper. We feel that in focusing on but two faces of the Monument we can still provide insight into some of the ways in which people re-enacted specific historical events in the landscape during the two observed periods.
} 


\section{"A PLACE OF GATHERING, A PLACE OF NEW CREATION" - THE CREATION OF THE MONUMENT TO THE PEASANT REVOLT AND MATIJA GUBEC}

"Now we have a monument to the Peasant Revolt around which hundreds of people from all over the country gather daily. As was once customary to go on a pilgrimage to Marija Bistrica, today the same journey is taken to visit the monument in Stubica. No monument has attracted so many visitors, and that fact speaks for itself, proving that the monument is fulfilling its intended function". (Sabolić 1974:84-85).

The intention of this chapter is to refer to the relationship with the past that is re-enacted by erecting a Monument to the Peasant Revolt and Matija Gubec, that we have been following through available sources like newspaper articles, writings of politically and socially engaged persons of the time, monographs published on important occasions and professional periodicals. The end of WWII and the introduction of a socialist political system marked the beginning of a new era in which the ways of interpreting and using the historical figure of Gubec were largely determined by the ideological worldview and political reversals in the Socialist Federative Republic of Yugoslavia. From sporadic announcements during WWII in which the revolt embodied in the figure of Gubec calls for denouncing authorities and joining the Partisan movement (cf. Žanić 1998:315-320) to post-war rhetoric which tries to pacify his rebel spirit, the activation of the symbolic potential of the Peasant Revolt and Matija Gubec has been adapted to the needs of time, changing accordingly its dynamics, rhetoric and addressees. In spite of creating a dominant narrative about Gubec's rebellion which paved the way to the Yugoslav Front of the World War II and Tito's historical greatness, the political discourse on Gubec during almost 50 years of the Socialist Federative Republic of Yugoslavia should not be considered static and petrified. In socialism Matija Gubec is depicted as a dynamic, complex and layered phenomenon that has been changing its configuration and adapting to new contexts. Unlike the war cries of Gubec's name ${ }^{5}$, reaching for the revolutionary aspect of his subsequently written biography in times of peace did not call for the "clinking of weapons" but rather for the post war recovery of the country and putting in place the socialist 
system. Also, when it comes to constructing adequate social remembering, the emphasis is transferred from Matija Gubec to the Peasant Revolt because it symbolises the power of the proletariat. In the dissemination of ideological heritage of a barely finished "socialist revolution" and "national liberation" that stuck to the already proven tenets of media propaganda (Senjković 2008:59-60), the topos of the Peasant Revolt became an apt metaphor for the values of liberty, brotherhood and unity. For example, in Miroslav Krleža's speech in Stubica in 1951, the historical martyrdom of the peoples of Yugoslavia is evoked by means of remembering the Peasant Revolt which is, according to Krleža's interpretation, a reflection of "the will for national freedom, social justice and equality" and "a signpost in dark historical times (cf. 1975:[s.p.]). Its significance for the present times, comparable to the French Revolution and the socialist revolution under the leadership of Josip Broz Tito, is further emphasized by Krleža by means of a dramatic description of the fatal battle, images of light and darkness, good and evil, disenfranchised people and the arrogant potentates.

Ideas on how to appropriately mark the monument to the Peasant Revolt and Matija Gubec fell on fertile ground in subsequent years, which resulted in specific proposals for putting up memorials devoted to them. ${ }^{6}$ Thus, for example, in a newspaper article from 29 October 1954 published in Glas Hrvatskog Zagorja and entitled "Augustinčić and Zagorje", which

\footnotetext{
5 A clear example of evoking Matija Gubec's revolutionary tendencies during WWII is noticeable in Tito's address to the Croatians. Tito evoked the memory of Gubec "who fought for freedom and justice in the past" (Damjanović 1983:61), while he instructed the partisans to "sing partisan songs" as they pass through Croatian villages, "especially the song about Matija Gubec in order to instigate rebellious feelings and mass physical resistance of the Croatian peasants and broad masses of workers" (Jelić 1973:336).

6 Josip Mataić, one of the members of the Committee for the Celebration of the Peasant Revolt quadricentennial, states in his records of the first ideas about the monument that the first Committee for monument building was set up as early as in 1951. However, it did not come to be at the time. Monuments to the Peasant Revolt were erected as early as in 1962. According to the data provided by the current Museum of the Peasant Revolt Director, Vlatka Filipčić Maligec, a memorial was put up on Kapelščak hill in the same year and a memorial plaque was put up on the house under Gubec's linden tree by mountaineers (2010:72).
} 
depicted life and work of the most famous sculptor from Zagorje - Antun Augustinčić, a special emphasis is given to his deep connection to Croatian Zagorje which "calls and attracts him", which speaks to him in "that special voice of childhood experiences and first excitements" (Krklec 1975: [s.p.]). Although the article pays tribute to his work and states that his "monument to Marshal Tito in Kumrovec still sounds its bronze echo", it raises a question of Augustinčić could pay the debt to his native Zagorje in the form of a monument to one of Zagorje's greatest sons. "Stubica is there, with the old linden tree in the village... As soon as I meet him, I shall whisper in his ear, how wonderful it would be if he could design and create another piece, a monument to Matija Gubec in his birthplace". (ibid.). The Committee for the celebration of the quadricentennial of the Peasant Revolt was set up in 1966 in response to Krleža's considerations on the significance of the Peasant Revolt and Matija Gubec in the current political moment (cf. Vujčić 2013:3). ${ }^{7}$

"In a historical setting especially characteristic of Stubica, hills and vales, villages, hamlets and settlements exude an air of history" (Zdunić 1975 :[s.p.]). Cultural policy makers of the time were of the opinion that in building a monument in a space that exudes history, to borrow Drago Zdunić's words, the ambience of the space and its historical component needed to be taken into account as well as its physical properties. The first attempts at evaluation of the natural ambience in which the intervention was planned underline the state of disrepair and neglect of Samac hill in Gornja Stubica, which the construction of the monument was to address. After the hill had been cleared of acacia coppices and overgrown vineyards, nature and landscape potential became evident, which made it possible for the monument to be seamlessly embedded in the historical dimension of the space (Mataic 1975: [s.p.]). During the time of drafting its concept

\footnotetext{
7 In the article "Sketches from prehistoric times of the Peasant Revolt Museum (from the Museum's newspaper library 1959-1973 and the documents on Museum establishment) Vlatka Filipčić Maligec references 1963 as a year in which the Committee was founded (2010:72), with a remark that the Committee did not become a reality in that year. Matija Gubec monograph, published on the occasion of the anniversary and Memories of the Monument publication both cite 1966 as the year of its founding (c.f. Zdunić 1975; Vujčić 2013:4).
} 
design on a historical stage with dense symbolic interlinkages, the answers to questions about what the Monument should be dedicated to and in what ways memory should be recorded in space, were often changed and expanded. ${ }^{8}$ The original plans of a memorial to the Peasant Revolt were subsequently expanded to include the construction of a number of facilities, such as a road called Yugoslav People's Army Linden Avenue, which would connect the Monument with the Oršić Palace thus "completing a logical whole of authentic historical events" (ibid.). ${ }^{9}$ The request for respecting the special characteristics of the setting became even more prominent in the legal provisions of the Law on Erecting Monuments to Historical Events and Persons that stipulated that monuments "make an organic whole with real life" (Vujčić 2013:5). Considerations of Josip Mataić, the president of the Fund for the Monument Construction and the celebration of the Peasant Revolt quadricentennial, which was founded on 20 March 1969 in

${ }^{8}$ Initial ideas about a memorial to the Peasant Revolt speak of the need to have a monument to Matija Gubec (c.f. Krklec 1975:[s.p.]), and only later it a monument to the Peasant Revolt mentioned (Mataić 1975:[s.p]). The institutional coordination of memorial area and facilities began with the setting up of the Fund for the Monument Construction (ibid.; Vujčić 2013).

${ }^{9}$ On the anniversary of the Peasant Revolt many tourist agencies organized excursions to Gubec's native land and the winners of school history competitions were often awarded visits to Gubec's native land (Mataic 1974:93). Newspaper headlines report on the tour "Following in the footsteps of Zagorje and Gubec's brigades", which included visiting historical sites in Croatian Zagorje that are important for understanding the history of the Yugoslav Front of WWII and the Peasant Revolt. The tour ended in students' parade along the Yugoslav National Army Linden Avenue and in an assembly under Gubec's linden tree where WWII soldiers told children their memories of Partisan days, which were completed by references to Matija Gubec (c.f. N.R. 1972:7). "Right here, under this tree, and on Zagorje soil, where we keep the tradition worthy of a hero such as Matija Gubec and the ideals that he fought for. A file of young men and women carrying flags were brought to this historical place by soldiers of the Yugoslav Front of WWII, presidents of war veterans' associations from Varaždin and Donja Stubica, comrades Franjo Žitnjak and Fabijan Sukelj, in order to tell them a few proud words about what Matija Gubec had started and Josip Broz Tito finished on the lines of what Miroslav Krleža wrote about this place some twenty years ago: 'Our will to live today is the will for social justice, egalitarianism, equality and national freedom, these were the slogans under which Matija Gubec and his Stubica comrades had given their lives"” (ibid.). 
Donja Stubica, go along the same lines. A few days before the unveiling ceremony Mataic said that "the monument gives the impression of having been standing on this spot for hundreds of years" (Mataić 1975: [s.p.]).

The first outlines of the monument to the Peasant Revolt and Matija Gubec began to emerge in the 1960s, when Antun Augustinčić was contacted by the members of the Committee asking him to come up with a concept design for the memorial space. However, the adoption of the Law on Erecting Monuments to Historical Events and Persons from 1967 temporarily put Augustinčić's work on the project on hold. ${ }^{10}$ Namely, according to the above mentioned Law, "a general nation-wide, anonymous tender" had to be launched prior to the building of a monument of architectural or artistic significance. One of the provisions in the tender called for the monument to be built at the foot of the Oršić Palace, popularly called Gubec's home, without spoiling the landscape characteristics. More than 80 different concept designs were submitted for assessment by the jury of experts, which consisted of renowned art historians, authors, artists, civil engineers, urban planners and architects, provoking different and often contradictory reactions to the visions of the future monument. "Opinions on sculptors' searches for new forms and their rebelling against the conventional representations were expressed; the difficulties in transforming an idea into a symbol were discussed together with the monument's purpose and future and the ways in which it could be reconciled with the environment and the palace." (Vujčić 2013:6). Disagreement among jury members led to shortlisting 6 designs, although they were all characterized as excessive and either ambiguous in terms of ideas or unnaturally abstract so that they could not be embedded in the picturesque landscape near the Oršić Palace (Filipčić Maligec 2010:74-78). ${ }^{11}$ Moreover, even newspaper articles that

\footnotetext{
10 Official Gazette, no. 1, year XXIV, 12 January 1968.

${ }_{11}$ Upon the completion of the tender, all of the 86 works that participated were exhibited at the Art Pavillion. Branko Ružić's work no. 37, which was the runner-up, provoked the most discussion among jury members, but also in the media space. For example, Večernji list published and article "A bit of joke, a bit of reality - on the monuents to the Peasant Revolt", in which the author poses the following question: "What would a person from Zagorje say if he saw the legendary Peasant Revolt depicted as three upright bludgeons and a line of concrete walls stacked together?" (Filipčić Maligec 2010:78)
} 
were following the discussions between advocates for and against the abstract vision of the monument, sided with those who criticized the runnerup Branko Ružić's design. It reminded a journalist of the Večernji list daily Vlado Novak of "lunar modules, advertisements for plywood or Ferimport (chain of DIY stores; translator's note), Pharaonic tombs" (ibid.). In contrast to the abstract proposals, figurative concept designs, which Antun Augustinčić had preferred, were more acceptable to the jury members. After the decision had been made not to award the first prize, the jury directly contacted Antun Augustinčić with an ad hoc offer and he accepted the task of creating the monument. The construction lasted two years and the monument was completed a few days before the ceremony marking the quadricentennial of the Peasant Revolt on 14 October 1973. Augustinčić designed the monument to the Peasant Revolt and Matija Gubec as a "great stage for historical events" (Mataić 1974:95), "a panoramic vision of people's life and suffering", that is to say "a place where people gather, a place for new creation" (Mataić 1975: [s.p.]). Therefore, he designed it as an open stage carved into a hillside from where there is an open view of Donja Stubica. The backdrop to the monument consists of two wings 20 meters long and 7.5 meters tall. The left wing depicts an image of the battle of Stubica, while the right offers a collage of characters from Krleža's collection of poems Ballad of Petrica Kerempuh (c.f. Vujčić 2013:10-12). The figure of Matija Gubec is a departure from the figurative narration of the monument's wings with arms spread, outstretched towards the sky with clenched fists. It is 6.5 meters tall and Gustav Krklec described it as a tragic figure which is at the same time an invisible link between two past, i.e. "a symbol of a folk leader engaged in conflicts long gone at odds with unsustainable reality" (Krklec 1975: [s.p.]). The figure of Matija Gubec in the central part of the dais dominates the Monument and is juxtaposed with the figure of Petrica Kerempuh, Krleža's folk chronicler and caustic observer of a century-long oppression of the people. Augustinčić's contemporaries also found their place in the figurative narration of the Monument such as Miroslav Krleža ${ }^{12}$ positioned on the left wing of the Monument observing the battle of Stubica, Josip Mataić, president of the Fund, and on the right

${ }^{12}$ Krleža was located on the left hand side as an observer of historical events. 
Vladimir Herljević, a sculptor who collaborated with Augustinčić and Velibor Mačukatin. Positioning the living contemporaries in the relief representation of a historical event and in the phantasmagorial Ballad of Petrica Kerempuh literary work, and constructing a dais, which makes it possible to enter the space that emanates history, indicate the omnitemporal universality of the Peasant Revolt.

From today's perspective the ceremony of unveiling the Monument in Gornja Stubica appears to be a combination of highly stylized and formalized commemorative celebrations. Newspaper articles and occasional publications like monographs complete the atmosphere with a festive mood. They report on the audience's piety, Yugoslav Republics' flags and banners addressed to Tito and Gubec. Descriptions of events that took place on the day of the ceremonial unveiling of the Monument not only abound with exact protocol detail, but also help create a feeling of mysticism that envelops the overall occasion. Thus, there is a description of the fog that hangs over the Monument but recedes just as Tito approaches it and there is a clear view from Gubec's home on the valley filled with visitors. "In the valley below, a unique sight: a sea of vehicles emerges through the fog, whole fields are overflowing with them, all roads are filled with buses and cars, rows of trains are on the railway tracks, and people are still pouring in" (Mataic 1974:97). Soon a line of cars with Tito emerges from the multitude. He is greeted by the Yugoslav People's Army, and young men and women dressed in folk costumes. "The gathering place is chock-full and looks like a beehive. Flags are flying; people are cheering and applauding to comrade President and other guests. Everyone is elated and comrade Tito is overjoyed and in a very good mood." (ibid.). The formalised and performative languages are intertwined, as Paul Connerton points out (1989:58), which helps create authenticity, sincerity and the sanctity of the Peasant Revolt and the figure of Gubec and is especially emphasised on the day re-enacting the figurative narration in the background. It speaks of the figure of Gubec, the Peasant Revolt and its place in the history of the Yugoslav Front of WW II. Gun salutes are fired, the national anthem is performed ceremonially, praising the socially acceptable image of a folk hero who contributed to the development of socialist, liberal, national ideas. Jakov Blažević, the Speaker of the House in the Socialist Republic of Croatia, 


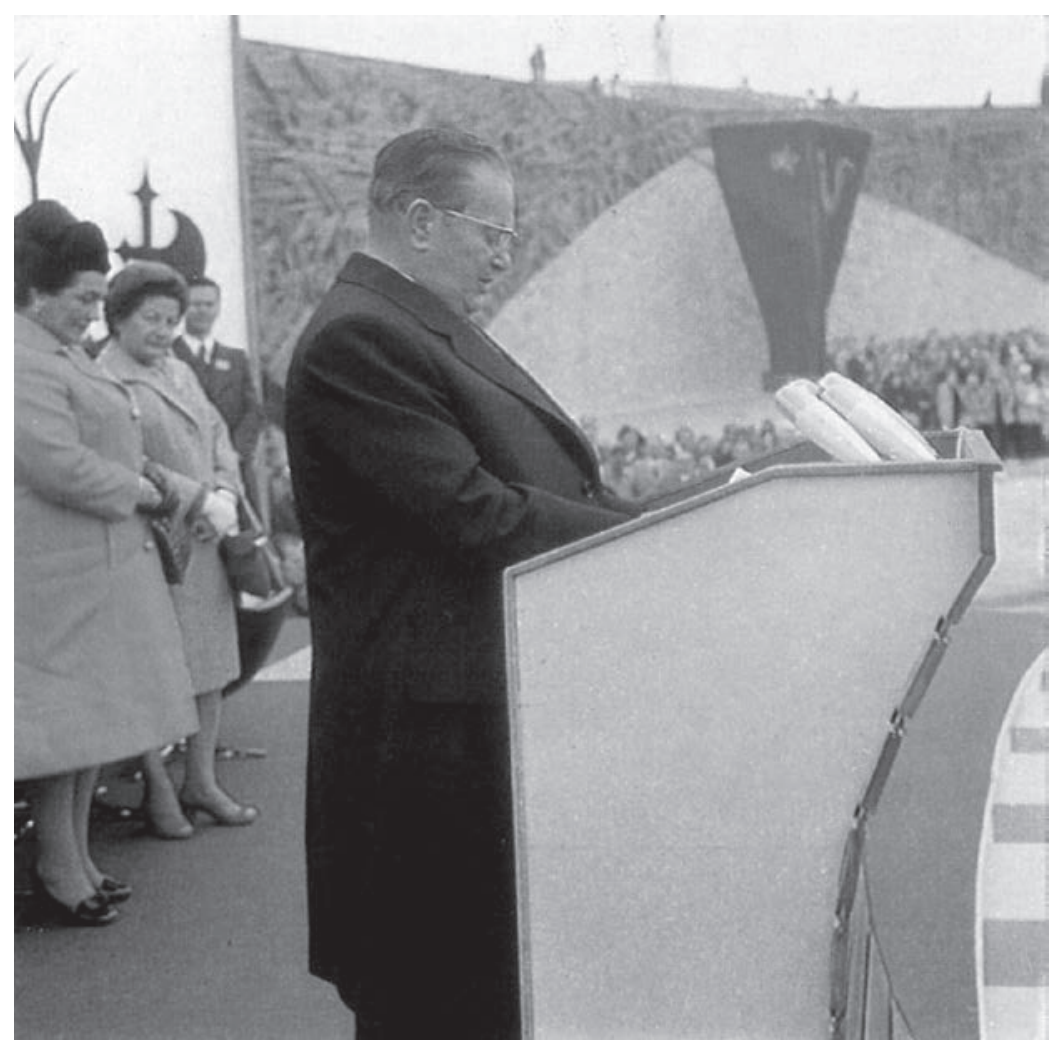

Figure 1: Josip Broz Tito before the ceremony of unveiling the Monument to the Peasant Revolt and Matija Gubec on October 14, 1973. Source: Zdunić, Drago, ed. 1975. Matija

Gubec: monografija o spomeniku Seljačkoj buni i Muzeju seljačkih buna u Gornjoj

Stubici. Gornja Stubica: Muzej seljačkih buna, Zagreb: Spektar, p. 44

pointed to the importance of the Peasant Revolt in his speech. He characterised Augustinčić's vision of the revolt as "a monument which will re-enact history and connect it with the socialist present". (1974: [s.p.]). The incumbent Zagreb mayor, Ivo Vrhovec, saw the monument as a link between the liberal past and the socialist future (c.f. Zdunić 1975: [s.p.]). Just before Tito ceremonially took the cover off the monument (Figure 1), the choirs began to sing "a rebel song 'Zdignite brati zastave, hej!' [Brothers, lift up your flags, hey!]” (Mataić 1974:98). "At that solemn moment, the multitude fell silent, and a sonorous choir song was heard while the flag-bearers raised the flags gradually revealing the figure of Matija Gubec" (ibid.). In order to strengthen the link between 
the figures of Tito and Gubec, who are continuously described as "the leaders of the masses in two different periods (...) two men of the same kind, two revolutionaries, rebels against the contemporary situation and oppression" (Kovačić 1972:8); the ceremony that marks the anniversary is given even more grandeur by planting a new linden tree, this time Tito's linden tree. Before taking a tour of the Peasant Revolt exhibition with an expert, during which Tito remembered "details of the Revolt, some places from his birth place where it took place, as well as folk customs" (Mataić 1974:99), Tito was welcomed by Ivan Goran Kovačić folk ensemble who performed a kolo and in doing so led Tito to the space designated for the planting of the linden tree. As he was planting the linden tree as a symbol of "brotherhood and unity, development, progress and peace for our peoples" (ibid. 98) peasants wearing folk costumes were assisting him thus giving legitimacy to Tito's "personality, who together with the Party, achieved the realization of the ideas that Matija Gubec had carried in his consciousness for all our peoples". (ibid.100). Gubec's linden tree, which oral legends describe as a meeting place of all rebelling serfs (c.f. Zečević 1969:12-13; Bonifačić Rožin 1966:15), and the linden tree planted on the occasion of the quadricentennial together symbolise the cycle that began with the revolt led by Gubec and is completed in Tito's time, thus transcending the particularities of space and time (c.f. Halbwachs 1992:200).

Soon after that the Monument became not only a destination for school trips, trade union and family excursions, but also for the visits by political organisations, football clubs, etc. Being a reflection of "the freedom loving spirit of our people that suffered under the centuries-long oppression" (Zdunić 1975: [s.p.]). In the next few years the monument attracted more than 70000 visitors from all over Yugoslavia and beyond: from Czechoslovakia, Italy, Romania, USSR, Germany, Belarus, France, USA, several South American states and Australia to China. Most visitors favoured Augustinčić's vision of Matija Gubec and the Peasant Revolt, judging by the large number of positive comments in the visitors' book which was opened to the public on the occasion of the unveiling ceremony. The impressions from the visitors' book depicted the monument as "the most beautiful work in our country" (ibid.), i.e. as something "monumental", "majestic", "functional", "unobtrusive", "extraordinary", 
and even "authentic" (ibid.). One of the visitors concluded: "In our freedom loving country, even our hero Matija has become free" (ibid.). A visitor form Belgrade wrote: "Past, present and future will live inside us like a meteor light, (...) as the memory of Matija Gubec somewhere deep in our hearts" (ibid.). Matija Gubec's ideals, which were ahead of his time, were manifested in the monument as a tangible expression of the utopia of egalitarianism that was ingrained in the socialist everyday life and in the visitors' experience.

\section{HISTORY RE-ENACTED IN THE CONTEMPORARY - THE USES OF THE MONUMENT TO THE PEASANT REVOLT AND MATIJA GUBEC IN THE $21^{\text {ST }}$ CENTURY}

In the 1990s, within the context of the Croatian War of Independence and the establishment of the independent Republic of Croatia, the historical monuments that were created during socialism were used as one of the many platforms for reidentifying the nation and constructing adequate national remembering that legitimises the established social system (c.f. Connerton 1989). They were also used to encourage collective oblivion when it comes to the previously valid "glorious pasts", particularly those connected with the Yugoslav front of WW II and the creation of Yugoslavia. Since these monuments were symbolically equalized with the aggressors and enemies of Croatia, many of them became undesirable objects. Therefore, they often disappeared from the public, especially open spaces or were put out of the visitors' reach: i.e. they were locked in museum and galleries' storage spaces; transferred to public institutions' basements; or were forgotten in the landscape where, neglected by the authorities, they gradually fell into disrepair (Potkonjak and Pletenac 2011:13). In some instances they were targets of vandalism or - as is the case with Augustinčić's monument to Josip Broz Tito in Kumrovec - were blown up by explosive devices (Belaj 2006:201).

There were no interventions into the physical appearance, landscape or the site of the Peasant Revolt monument either at the time or subsequently. Its historical monument status and its categorization as a museum object belonging to the collection of the Peasant Revolt Museum, 
which became a part of the Museums of Croatian Zagorje in 1992, stayed unaltered. The monument itself remained a prominent tourist destination in the post-socialist period and was often advertised by emphasising that: "for most Croats the name of Gornja Stubica is synonymous (...) with Matija Gubec, the leader of the Peasant Revolt from the 16th century". ${ }^{13}$ It is a spot not to be missed in cultural tourism routes that underlined its connection with the Peasant Revolt (for example a 35-kilometer circular cycling tour is entitled "Through Gubec's Native Land", a hiking tour is organized under the name of "The Path of Gubec's Rebels", etc.). ${ }^{14}$ Apart from being a destination recommended by tourist agencies to organized groups of school students, pensioners, various other associations and individual visitors coming to Gornja Stubica, the monument is also a part and parcel of the political itinerary at the local, regional and national level, especially on the occasions of Revolt anniversaries. ${ }^{15}$ Thus the Peasant Revolt theme and the figure of Matija Gubec are connected with the concepts embedded in the foundations of political programmes, with the aim of supporting the idea of continuity and sustainability of particular political persuasions and methods of social activity. For example, during his last visit to Gornja Stubica in 2013 on the occasion of the 440th anniversary of the Peasant Revolt, former President Ivo Josipović analysed the role of Matija Gubec in the Croatian history and added an air of contemporary history to the idea of justice that he emphasised as one of his fundamental political goals: "Zagorje was the birthplace of many great personalities, one of whom is Matija Gubec. So many years after the revolt we are still admiring that man because he had the idea of justice, and the same idea must move people today, too. We shall fight for that justice" (sp/VLM 2013). In similar ways the images of the past connected with the Peasant Revolt are evoked at the stage at the foot of the

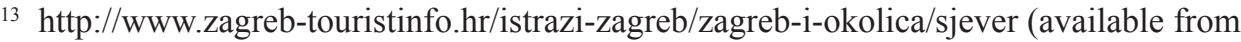
$10 / 3 / 2015)$

14 http://www.tzzz.hr/biciklisticke-karte/karta-3/ (available from 10/3/2015); http://www. hpd-kapela.hr/docs/stazama\%20gupcevih\%20puntara\%2007.01.2015.pdf (pdf available from 10/3/2015)

${ }^{15}$ According to the Museum of the Peasant Revolt data in the second half of the 20th century the Ministry of Culture of the Republic of Croatia used to take its distinguished guests on a tour of the Monument relatively frequently.
} 
hill where the Monument is situated, during election campaigns, assemblies and other public events organized by the political parties. ${ }^{16}$

The component that has changed in these festive situations in comparison to commemorations and ceremonies which were held around the Monument in the socialist period is the addressee, i.e. persons and groups that are usually presented as comparable to the long perished Peasant Revolt participants, as a kind of Matija Gubec figures of our time. Therefore, references to Tito and the Yugoslav Front of WW II are taken out of the narratives and practices connected to the Monument as socialist equivalents of the main hero and the Peasant Revolt ideals. Expressions such as brotherhood, unity, progress and (workers') self management are also removed from the rhetoric. Such detachment from the previous patterns of remembering is a reflection of the resemantization of Matija Gubec and the Peasant Revolt that are noticeable in the broader social context. On the other hand, the imagery of the Peasant Revolt remained an extremely potent location for new meanings and references to the current social needs even in the independent Republic of Croatia. Events that had generally been described as actualizations of protagonists and motives of the 16th century Revolt in the media discourse were connected with farmer protests and road blocks in the northern part of Croatia from 2010 on. Hence just after organized farmers' protests began, Mile Prpa, an author and columnist, sees the road blocks in Zagorje, Podravina and Slavonia as an echo of Gubec's fight for justice and a kind of a democratic intervention of the disenfranchised in a highly stratified society:

\footnotetext{
${ }^{16}$ According to the words of the Museum oft he Peasant Revolt staff members, representatives of the Croatian Democratic Union and the Croatian Peasant Party organized events on the stage at the foot of the monument. However, they emphasised that in using this space multiparty system was visible, that is to say heterogeneity in expressing various political aspirations and ideas (based on the transcript of the interview with Vlatka Filipčić Maligec, from 10 February 2015). In other words, the space around the monument is not being occupied by only one political option nor is the monument being experienced in line with only one political quota system as is the case with places of memory related to other eminent historical persons who are often linked to Matija Gubec and referred to as "the three great sons of Croatian Zagorje" - with monuments and places of birth of Josip Broz Tito and Franjo Tuđman (c.f. Belaj and Škrbić Alempijević 2014; Škrbić Alempijević and Hjemdahl 2006).
} 
"The Peasant Revolt A.D. 2010 - the same battle is still being fought today albeit by different means, namely by tractor road blocks which are coming closer and tightening their grip around Zagreb, political and business capital of Croatia. Contemporary Tahys (oppressors) [are] taxes, tycoons, the mafia, bureaucracy, selling off Croatian national heritage, disregard for Croatia (...). It seems that there are signs of resistance to the politics of degrading and disenfranchising all that is Croatian, all that is patriotic. But who are going to be our new saviours after the likes of Nikola Kupinić, Josip Thurni, Gašpar Alapić that will dispel and 'defeat' this contemporary 'army' of peasants that is gathering from all sides and whose numbers are rising in the fight for justice of old? Who will be those to follow in the footsteps of famous serfs and fighters like Matija Gubec contemplating, like their predecessors, not only the fight for justice of old, but also how to root Croatia in the foundation of work, order and justice, in the foundation of dignity, humanity, patriotism and courage?" (Prpa 2010)

The author's comment clearly demonstrates that the notion of the fight against a superior enemy for the ideals of social justice, dignity, freedom, peace, etc. is summarized in the Peasant Revolt syntagm and embodied in the figure of Matija Gubec which represent a fertile ground for imagining the Croatian present and creating a vision of a better future based on the perception of our nation's heroic past. As was already indicated in the above mentioned quotation, there is another category which is presented as a contemporary successor of Gubec's struggles, that is to say Croatian war veterans, participants of the Homeland War. The fact that actualization of the Peasant Revolt heritage is one of the identification strategies for many groups of war veterans is further corroborated by the account of a staff member from the Peasant Revolt Museum, ${ }^{17}$ saying that Homeland War Veteran Associations' visits to Croatian Zagorje regularly include tours of the Monument in Gornja Stubica and taking photographs in front of it (c.f. Gaši 2009).

The basic purpose of the above mentioned usages of the Monument in the post-socialist period, which are primarily connected with commemorations and anniversary celebrations, is the inauguration of new

17 Based on the transcript of the interview from 10 February 2015. 
historical truths that are symbolically profiled as being opposed to the socialist politics of remembering, although their structure constitutes of the same elements that are used for creating the politics of remembering. However, alongside a corpus of protocol related procedures and narratives which imply the existence of a monolithic national History, from the beginning of this century the Monument has also been linked to more relaxed and heterogeneous usages of history, namely those that define themselves as syntagms for creative reshaping of the past by involving as large a number of participants in their own (re)creation of the historical events and persons that are re-enacted in performances. We are referring to festivals, performances and other public events which have been designed as "portals into the past", as arenas in which history is staged not only for the purpose of its better recognition and understanding, but also in order to allow different participants to experience it through their own senses and make it real once again in their performances (c.f. Škrbić Alempijević 2012:185-212). The analysis of such phenomena and processes is based on the review of two public events which used the space around the Monument to Peasant Revolt and Matija Gubec and indeed its surface as a stage: multimedia 3D video mapping performed on the monument itself in 2013 by Gubec Theatre and Chivalry Tournament that has been held in Gornja Stubica since 2000. In researching these events we relied on heterogeneous methods and sources: observing Chivalry Tournament in 2014; interviews with organizers of both events; Gubec Theatre's event presentation made on 1 December 2014 as a part of MUVI 05 events organized by the Museum Documentation Centre; analysis of literature dedicated to these events; media reviews; tourist materials; Internet forum discussions, etc. ${ }^{18}$

\footnotetext{
18 There is another event which directly evoked the images of the past in connection with occurrences and characters from the 16th century entitled the Peasant Revolt 1593. It is a several day event that takes place at the end of January and the beginning of February and is organized by the Knights of the Golden Chalice Society and Gornja Stubica tourist board. It is held in several sites in Donja and Gornja Stubica (Matija Gubec's birthplace, Gubec's linden tree, the atrium of the Peasant Revolt Museum, etc.). It is a staging of the beginning of the Peasant Revolt in which performers wear reconstructed clothing worn by nobility, knights and peasants (c.f. Lozančić 2009:58-68). However, since none of the event segments take place directly at the Monument or in communication with it, and the event itself does not serve as a platform for the monument reinterpretation, unlike the two events which we analize in the paper, we did not include it in our research.
} 
"Gubec Theatre's multimedia 3D mapping was a part of anniversary celebrations. The aim was to use multimedia animation of the monument to depict the Peasant Revolt. All of a sudden many characters depicted in the relief could walk, fly or lunge into battle. The multimedia 3D mapping lasted for 15 minutes and was accompanied by music and a recital performed by Vid Balog who was reading the excerpts from the Ballad of Petrica Kerempuh written by Miroslav Krleža; parts from Habdelić's description of the Peasant Revolt dating from the 17th century; and a selection of passages from the so-called (serfs') claim against Tahy, whose original from the 16th century is kept at the Croatian State Archives. The demanding animation of the selected scenes from the Monument succeeded in 'breathing' new life into the characters."'19

This was the way in which Novena ltd., a professional digital media studio described the multimedia show in which it participated together with Pago Com ltd., a company specialized in technical event production. Gubec Theatre event was performed once on 18 October 2013 before audience of more than a thousand members as the central part of celebrations marking the 40th anniversary of the monument complex and the Museum in Gornja Stubica and the 440th anniversary of the Peasant Revolt under the auspices of the President of Croatia, Ivo Josipović, who was present at the event and on that occasion delivered a speech on the significance of the Peasant Revolt's messages in the present day. ${ }^{20}$ The Peasant Revolt Museum was the organizer of the event whereas museum consultant Goranka Horjan was the author of the conceptual design and the script. Speaking about what prompted the organization of such an event Ms Horjan underlined that "we wanted to (...) show and animate the monument which has been located near the Peasant Revolt Museum for forty years in a new way by using a combination of new technology and performance arts." ${ }^{21}$ Gubec Theatre

\footnotetext{
19 http://www.novena.hr/hr/novosti/gubec-teatar,140.html (available from 10/3/2015)

${ }^{20} \mathrm{https}$ ://www.youtube.com/watch?v=7rJMILDMrJI (available from 10/3/2015)

21 Based on the transcript of the project presentation by Goranka Horjan on 1 December 2014 as part of MUVI 05 events: museums-video-film, organized by the Museum Documentation Centre.
} 
performance was a combination of animation, whose main characters were figures from the monument, Miroslav Krleža and his Petrica Kerempuh among others, and excerpts from the film The Peasant Revolt 1573 directed by Vatroslav Mimica, videos of the Peasant Revolt 1573 event held in Donja and Gornja Stubica, and the light show projected onto the wings of the Monument. Literary works connected with the topic of the Peasant Revolt, namely Krleža's Ballad of Petrica Kerempuh and Juraj Habdelić's First Sin of our Father Adam were used as literary templates together with quotations from the serfs' claim against Franjo Tahy in the court proceedings. Additional music was performed by Minstrel medieval music ensemble and was supposed to evoke the atmosphere characteristic of the time that was re-enacted. The event was a contemporary performative reinterpretation of past events which added another layer of meaning to the monument surface and gave it new possibilities of interpretation and experience. Nevertheless, the historical grounds of the performance were chosen by the project authors as a concept in order to establish closer connections between this multimedia event and the space of the monument dedicated to Gubec, whose character was defined in the following way within the context of the project: "A symbol of centuries long fight of the little man for justice which is why we decided to stage the story about the Revolt and its leader in line with the new times. ${ }^{\prime 22}$ In this way the event renders additional aspects of remembering and performance to the monument as a place of remembrance.

Re-enactment and at the same time memory creation through performance is the essence of the next event that we look into, namely the Chivalry Tournament in Gornja Stubica:

"In an attempt to draw as many visitors as possible and give them an opportunity to experience the past in a new way, since 2000 the Peasant Revolt Museum has been offering its visitors a chance to step out of the hustle and bustle of the 21st century and step into a colourful world of the Middle Ages. On the day of the Chivalry Tournament in Gornja Stubica. (...) The idea behind the Tournament was to go back to the close of the Middle Ages, i.e. the second half

22 http://www.novena.hr/hr/novosti/gubec-teatar---nagrada-simply-the-best, 143.html (available from 10/3/2015) 
of the 16th century and the time before the great Peasant Revolt. From the very beginning we were aware that it was not possible to repeat the past so we tried to bring historical truth in line with our presentational possibilities." (Filipčić Maligec 2005:18).

This is how the organizers, representatives of the Peasant Revolt Museum in Gornja Stubica, described the phenomenon which was central to bringing the medieval times just before the serf uprising to the contemporary stage. At the same time the past that was being re-enacted through festival performances and enactments was not a one-way past offered to visitors as passive consumers. Quite the contrary, this past was grounded in the everyday life thus enabling the visitors to enter the space of its creation. The Chivalry Tournament was designed as a part of a larger project entitled "The Middle Ages in Croatian Zagorje" in an attempt to "breathe new life" into the historical heritage of the region (Horjan 2009:430). This is a one day cultural and tourist event which takes place in June with the participation of several hundred performers and several thousand visitors (ibid. 442). The aim of the event is to provide visitors with an opportunity to participate in an event "that re-enacts selected episodes from the late Middle Ages or early Modern Times", i.e. to offer the experience of history of the period, its customs and the way of life, in an innovative way (ibid.). Although the organizers saw the Tournament as a platform on which all the classes of the former feudal society could be presented, performers who dominated in the performances as well as the number of performances on the programme together with the name of the event all demonstrate that the odds are in favour of the knights as symbolic opponents of the peasant class whose chivalry was materialized at the site of the monument. (Figure 2) In other words, the backbone of the Tournament consists of staged jousting, horseback riding stunts and competitions in different events such as: pumpkin cutting with swords, spear throwing, ring jousting, etc. which take place on the battleground at the foot of Samac hill and of the monument (Filipčić Maligec 2005:19; Horjan 2009:434). The knights take central stage in other events such as night siege of the city, i.e. the Oršić Palace. Many knight societies' members participate in pitching army camps dressed in different costumes: the Knights of the 


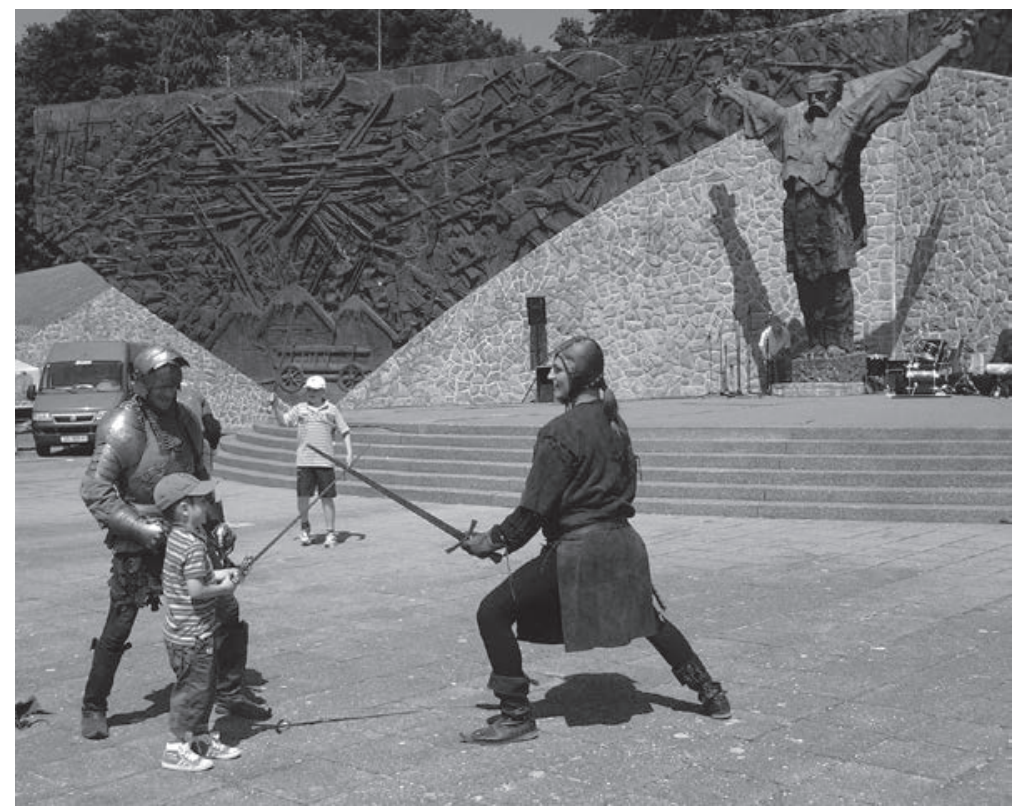

Figure 2: Participants of the Chivalry Tournament at the foot of the Monument to the Peasant Revolt and Matija Gubec in Gornja Stubica. Photo by Tomislav Oroz, 11. 6. 2011.

Golden Chalice ${ }^{23}$, Tahy's Musketeers, the Croatian Knight, the Knights of Zelingrad, etc. The societies in question perform their programme in many events and tournaments dedicated to medieval times all over Croatia. However, they adapt their performances to the site on which the past is being re-enacted. Their attempts to establish a connection between the generally acknowledged ideas about the Middle Ages with local specificities are substantiated by one of the performers who was in charge of the Glagolitic alphabet workshop at the Chivalry Tournament in 2011:

"Look, all the groups here, these knights' societies and those of us who work near the battleground, of course we are all a part of the

23 According to the Peasant Revolt Museum staff members, the society was established in part as a result of workshops and lectures organized at the Museum, which in time went beyond its walls thus offering an opportunity for a more liberal reinterpretation of history. Nevertheless, even today some Museum staff members actively participate in the Knights of the Golden Chalice Society activities (based on the transcript of the interview with Vlatka Filipčić Maligec, from 10 February 2015). 
Middle Ages. We go everywhere where people want to do something with it. (...) In other bigger countries, they make films and seize business opportunities, we are just getting started and we are happy if anybody wants to do something like this. This [Chivalry Tournament in Stubica] is after all an event, an exceptional event. The knights' societies are doing it for themselves, and yet we are re-enacting a part of history in a way... adapted to the story of the place we come to. Perhaps these battles were not of global importance, but they are important to the local people." ${ }^{24}$

Knight skills are being taught in heraldry and handling medieval weapons workshops as well as in Childrens' Chivalry Tournament. Thus the so-called high culture of the medieval period is also promoted in the way of dressing, medieval and renaissance music performances and court dances. Furthermore, knighthood is proclaimed as a historical and cultural value on the occasion of the festival opening. The actor who plays a nobleman - the host of the Tournament, extols the significance of the Tournament in preparing brave knights "for centuries-long war waging against the Turks. He refers to their honour and duty to defend their country and their Lord landowner, and urges them to keep their holy catholic faith and (honour) righteousness" (Horjan 2009:434). The chivalrous past of the Croatian people and the region is the past that can be experienced with all senses at the Tournament: aromas of traditional and medieval food, medieval fairground sounds, hot torches of fire eaters and fire jugglers, etc.

Some of the Tournament activities and segments take place in the immediate vicinity of the monument to the Peasant Revolt and Matija Gubec, in fact in the interaction with it. Besides the battleground at the foot of the hill where horsemen compete, the dais in front of the monument is also used to re-enact the past in the Tournament. For example, the dais is the place where opening ceremonies take place, knight societies parade, particular Tournament events are announced, court dances and stage sword fights are performed. In the immediate surroundings of the monument complex,

24 Based on the transcript of the interview with M. K., a participant of the Chivalry Tournament, from 11 June 2011. 
a medieval fair is set up, which incorporates the monument in its festival reality. In all these different facets of the Tournament, the monument does not only serve as a kind of backdrop, a spectacular set for a specific aspect of re-enacting history, but also as an indication that history has already been inscribed in this space and is open to new interpretations and experiences. The historical plane to which both materialized memories refer is the basis for connecting the monument with the Tournament, a perception about the 16 th century that is produced in the present in the form of practices linked to the monument as well as the tournament performances. The discrepancy in creating social memory in both contexts derives from the question whose heritage is being actualized and extolled in this place: the one connected with the Peasant Revolt or the chivalrous past? ${ }^{25}$ The organizers are very much aware of the problem, saying that the monument "does not really fit with the story of the Chivalry Tournament". However, they interpret the view of the medieval times from the knight's perspective in the context of the audience's expectations and needs:

"People like variety, a bit of pomp, they like everything to pivot on the higher classes whose clothes and customs are more interesting to them than the peasants themselves. (...) Our intention with the Chivalry Tournaments was to also show a part of peasants' life. Unfortunately, the figure of a peasant at the Tournament didn't attract as much attention. Alas, the peasants didn't fight on horseback. They didn't wear such fancy clothes. After all, they were not permitted to own swords or other weapons according to Werboczy Code, and these are all things that visitors like to see on a Tournament." 26

An awakened interest in the medieval times and knight culture has been noticeable in Croatia since its independence (c.f. Biti and Blagaić 2009). On

25 A further analisys of the views of Gornja Stubica inhabitants about the usage of the Peasant Revolt and Matija Gubec motifs in making their village into a brand and about what they thought were adequate ways of going about it, would shed more light on this issue. Unfortunately, such a research goes beyond the scope of this article, which primarily focuses on the analysis of the public events as a place of creating memory, on a particular episode in history and its protagonists.

${ }^{26}$ Based on the transcript of the interview with Vlatka Filipčić Maligec, from 10 February 2015. 
the one hand, it is a reflection of trends that are observable in festival industry all over Europe, and on the other it indicates new identification strategies on the national level, which treat Croatian medieval times as a potent place of symbolic re-foundation of the nation. The Chivalry Tournament in Gornja Stubica does not fit in with the trend. At last, the organizers emphasise that although the Tournament does not represent a direct reference to Matija Gubec and the Peasant Revolt, organizing events at the place of remembering that is dedicated to them at the same time encourages deeper awareness and experience of the past which the monument embodies. In view of the fact that we as ethnologists and cultural anthropologists do not separate events into those that are authentic, original and historically founded from those that are not, but rather see each such event as a place of creating culture (c.f. Kelemen and Škrbić Alempijević 2012), we perceive the chivalrous past memory reenactment only as one more corpus of heterogeneous cultural performances generated by the users of this place of remembering.

\section{CONCLUSION}

What can we conclude from the review of the two faces of the monument to the Peasant Revolt and Matija Gubec in Gornja Stubica? For us the thematization of the two faces of the monument meant focusing on the variety of practices that were awakened in the immediate vicinity of the monument, the purposes that were assigned to it and meanings that were inscribed in its manifestation. In other words, we were interested in the diverse uses of the monument more than the monument itself. In this respect, we viewed an episode in history which had ended more than four centuries ago as a basis for current social and cultural performances in which the monument was being revealed to us as a space where the real and the fantastical intertwined, dialogues between different truths took place, that is to say, the space where illusions about what is real fell apart thus opening the possibility of alternative histories performance.

The approach that enabled us to observe the behaviours in the immediate vicinity of the monument and the perceptions and experiences which it encouraged in socialist times on the same plane as well as look into how imagining of the past and alternative histories was played with and 
performatively staged in the post-socialist context, was our focusing on the dynamics around the monument from the perspective of performance in line with Goffman's thesis that every social interaction in the public space can be interpreted as a way of presenting ourselves to the others in the everyday life (1956). At the same time, Goffman's structuration of a performative situation by using terms such as "stage", "performers", "shows", etc., which derive from the analysis of interpersonal communication between several people, proved to be too narrow to encompass the complex and layered network of relations which is created between the participants in the public space, at the place of remembering, in a landscape filled with history. Namely, in our study the monument works both as a stage and as a generator of particular evocations of the past and performances of memory, as well as the addressee of these remembrances.

In discussing the heterogeneous people's perceptions and activities in the interaction with the monument, it is important to mention that unlike many other historical personalities who were proclaimed national heroes in socialism, Gubec undoubtedly continued to be a positive personality thus abundantly realizing his symbolic potential. However, regardless of the continuity of this type of valorization of his life and role in history, the concepts connected with Gubec and the ways in which his work is remembered are exceptionally variable and so can be observed as a reflection of the time in which they were practiced. In fact, highly stylized commemorative practices that took place at the foot of the monument just before it was revealed, lamenting the martyrdom of the defeated peasantry and Gubec's timeless ideals of freedom and equality, significantly differed from the ones that the monument had been connected with from the beginning of this century on when it was used as a backdrop for evoking romanticized medieval times by means of enacted battles with knights in costumes and children's workshops. In the first case, the dais of the monument complex was primarily defined as an arena for strictly formalized state ceremonies, which regardless of the strong commemorative structure, because it is open to the public, created the possibility of manifold parallel interpretations and uses of the motives linked to the Peasant Revolt. In the case of contemporary events, the monument is intentionally transformed into the space where the past is re-enacted by means of performances which need not be entirely true to the historical model. Whereas in the first case that we analyzed, brotherhood and 
unity were extolled as key values exemplified in the Peasant Revolt, in this century the priority is given to creativity and individuality as determinants of contemporary citizens, who remember the past but do so in their own way. In both observed contexts ideals such as social justice (at least in the rhetoric of certain political actors) and the sacrifice of the nation/common people for freedom and peace are places of concurrence in the creation of the politics of remembering connected with the monument.

The two faces of the monument to Matija Gubec and the Peasant Revolt that we refer to in the title of the paper do not imply two essentially different time periods. We are aware that there were examples that pointed to the more relaxed interpretations and experience of history that the monument inspired in the socialist period, too. Moreover, in the post-socialist era of festival or multimedia performances in Croatia the ceremonial, commemorative attitude to the monument, accompanied by the sounds of national anthems and formal speeches, did not abate in any way. Therefore, we understand the two studies that we have presented here more as a framework within which we are considering the dispersion of diverse memories and creations of the past, so that we deny neither the existence of different practices at the site, nor the intertwining, intermingling and mutual conditioning of the perceptions and actualizations of the monument in various episodes of history. In this respect, the two faces of the monument, i.e. the "monumental" one in which the glorious history of the nation is reflected and the "re-enacted" one which offers the possibility of different, creative enactments of past events, signify a point in which various imaginations of the past, perceptions of the present and visions of the future intersect. 


\section{REFERENCES AND SOURCES}

BELAJ, Marijana. 2006. "Tito poslije Tita. Kip Josipa Broza kao žarište obrednog ponašanja". In O Titu kao mitu. Proslava Dana mladosti u Kumrovcu., ed. Nevena Škrbić Alempijević and Kirsti Mathiesen Hjemdahl. Zagreb: FF Press; Srednja Europa, 201-219.

BELAJ, Marijana and Nevena ŠKRBIĆ ALEMPIJEVIĆ. 2014. "Remembering 'The Father of the Contemporary State of Croatia'. The Celebration of Tuđman's Birthday in His Birthplace". Traditiones, vol. 43:79-109. DOI: 10.3986/TRADITIO2014430107

BITI, Ozren and Marina BLAGAIĆ. 2009. "Vitezi na usluzi: preispisivanje tradicije u kulturnom turizmu Raba i Postojne". In Jedna granica - dvije etnologije?, ed. Željka Jelavić, Sanja Potkonjak and Helena Rožman. Zagreb: Hrvatsko etnološko društvo, 93-102.

BLAŽEVIĆ, Jakov. 1975. "Izvod iz govora na proslavi 400-godišnjice Seljačke bune 14. listopada 1973. godine”. In Matija Gubec: monografija o spomeniku Matiji Gupcu $i$ Muzeju seljačkih buna u Gornjoj Stubici, ed. Drago Zdunić. Gornja Stubica: Muzej seljačkih buna; Zagreb: Spektar, [s. p.].

BONIFAČIĆ ROŽIN, Nikola. 1966. Folklorna građa iz okolice Stubice. [Manuscript. 756 IEF].

BROZ TITO, Josip. 1975. "Ideali Seljačke bune ostvaruju se danas". In Matija Gubec: monografija o spomeniku Matiji Gupcu i Muzeju seljačkih buna u Gornjoj Stubici, ed. Drago Zdunić. Gornja Stubica: Muzej seljačkih buna; Zagreb: Spektar, [s. p.].

CONNERTON, Paul. 1989. How Societies Remember. Cambridge: Cambridge University Press.

DAMJANOVIĆ, Pero, ed. 1983. Josip Broz Tito sabrana djela: tom sedmi: kraj aprila 1940-28. Novembar 1941. Beograd, Zagreb: Izdavački centar Komunist; Beogradski izdavačko-grafički zavod; Naprijed.

FILIPČIĆ MALIGEC, Vlatka. 2005. "Viteški turnir - pokušaj oživljavanja prošlosti”. Informatica museologica, 36/3-4:18-23.

FILIPČIĆ MALIGEC, Vlatka. 2010. "Crtice iz prapovijesti Muzeja seljačkih buna”. Časopis za kulturu Hrvatsko zagorje, 3-4:72-86.

GAŠI, Sabit. 2009. "Plitvički branitelji na izletu u Zagorju”. Slobodna Lika.com, 6. prosinca, http://slobodnalika.com/novosti/4506_plitvicki+branitelji+na+izletu+u+ zagorju.html, access: 10. 3. 2015.

GOFFMAN, Erving. 1956. The Presentation of Self in Everyday Life. Edinburgh: University of Edinburgh.

HALBWACHS, Maurice. 1992. On Collective Memory. Chicago - London: University of Chicago Press.

HORJAN, Goranka. 2009. "Viteški turnir/ Knights Tournament”. In Arheologija i turizam u Hrvatskoj, ed. Sanjin Mihelić. Zagreb: Arheološki muzej, 430-442. 
JELIĆ, Ivan. 1973. “O značenju tradicije velike seljačke bune 1573. u povijesti komunističkog pokreta i revolucije u Hrvatskoj”. Radovi Instituta za hrvatsku povijest Sveučilišta u Zagrebu, 5:327-341.

KELEMEN, Petra and Nevena ŠKRBIĆ ALEMPIJEVIĆ. 2012. "Uvod: festivali kao mjesta stvaranja kulture”. In Grad kakav bi trebao biti. Etnološki i kulturnoantropološki osvrti na festivale, Petra Kelemen and Nevena Škrbić Alempijević. Zagreb: Naklada Jesenski i Turk, 7-14.

KOVAČIĆ, Zvonko. 1972. “Tražimo lik Matije Gupca”. [copy from personal archive of Vatroslav Mimica]. Vjesnik, 6-8.

KRKLEC, Gustav. 1975. “Uz Augustinčićev spomenik Matiji Gupcu i Seljačkoj buni”. In Matija Gubec: monografija o spomeniku Matiji Gupcu i Muzeju Seljačkih buna u Gornjoj Stubici, ed. Darko Zdunić. Gornja Stubica: Muzej seljačkih buna; Zagreb: Spektar, [s. p.].

KRLEŽA, Miroslav. 1975. "Govor u Stubici 1951. godine”. In Matija Gubec: monografija o spomeniku Matiji Gupcu i Muzeju seljačkih buna u Gornjoj Stubici, ed. Darko Zdunić. Gornja Stubica: Muzej seljačkih buna; Zagreb: Spektar, [s. p.].

LEFEBVRE, Henri. 1991. The Production of Space. Malden - Oxford: Blackwell Publishing.

LOZANČIĆ, Marta. 2009. "Seljačka buna”. National Geographic Hrvatska, 1:52-69.

LOW, Setha M. and Denise LAWRENCE-ZÚÑIGA. 2003. "Locating Culture", In The Anthropology of Space and Place: Locating Culture, eds. Setha M. Low and Denise Lawrence-Zúñiga. Oxford \& Malden: Blackwell Publishing, 1-47.

MATAIĆ, Josip. 1974. “Zapisi”. Kaj: časopis za kulturu i prosvjetu, 3-4:91-101.

N. R. 1972. “Omladina pod Gupčevom lipom”. Varaždinske vijesti, 27. svibnja, no. 1427:7.

POTKONJAK, Sanja i Tomislav PLETENAC. 2011. "Kada spomenici ožive - 'umjetnost sjećanja' u javnom prostoru”. Studia ethnologica Croatica, 23:7-24.

PRPA, Mile. 2010. "Seljačka buna A.D. 2010”. Hrvati AMAC, 9. ožujka, http://amac. hrvati-amac.com/index.php?option=com_content\&task=view\&id=3457\&Itemid= 192, access: 10. 3. 2015.

RIHTMAN-AUGUŠTIN, Dunja. 2000. Ulice moga grada: antropologija domaćeg terena. Beograd: Biblioteka XX vek.

SABOLIĆ, Ivan. 1974. "O počecima - spomeniku - muzeju”. Kaj: časopis za kulturu $i$ prosvjetu, 3-4:80-91.

SENJKOVIĆ, Reana. 2008. Izgubljeno u prijenosu. Pop iskustvo soc kulture. Zagreb: Institut za etnologiju i folkloristiku.

sp/VLM. 2013. "Josipović uveličao jubilej Muzeja Hrvatskog zagorja”. Večernji list, 18. listopada, http://www.vecernji.hr/sjeverozapadna-hrvatska/josipovic-uvelicaojubilej-muzeja-hrvatskog-zagorja-629829, pristup: 10. 3. 2015. 
ŠKRBIĆ ALEMPIJEVIĆ, Nevena. 2012. "Festivali i sjećanje. Studija slučaja: Ogulinski festival bajke". In Grad kakav bi trebao biti. Etnološki i kulturnoantropološki osvrti na festivale, Petra Kelemen and Nevena Škrbić Alempijević. Zagreb: Naklada Jesenski i Turk, 185-270.

ŠKRBIĆ ALEMPIJEVIĆ, Nevena and Kirsti Mathiesen HJEMDAHL, ur. 2006. O Titu kao mitu. Proslava Dana mladosti u Kumrovcu. Zagreb: FF Press; Srednja Europa.

ZDUNIĆ, Drago, ed. 1975. Matija Gubec: monografija o spomeniku Matiji Gupcu i Muzeju seljačkih buna u Gornjoj Stubici. Gornja Stubica: Muzej seljačkih buna; Zagreb: Spektar.

ZEČEVIĆ, Divna. 1969.-1972. Usmeno pripovijedanje u selima hrvatskog zagorja. [manuscript 1000 IEF sv. I., II., III.]

ŽANIĆ, Ivo. 1998. Prevarena povijest. Guslarska estrada, kult hajduka i rat u Hrvatskoj i Bosni i Hercegovini 1990-1995. Zagreb: Durieux.

http:/www.hpd-kapela.hr/docs/stazama\%20gupcevih\%20puntara\%2007.01.2015.pdf (Accessed 26 February 2015)

http://www.msb.mhz.hr/html/projekti/teatar.html (Accessed 26 February 2015)

http://www.novena.hr/hr/novosti/gubec-teatar,140.html (Accessed 26 February 2015)

http://www.novena.hr/hr/novosti/gubec-teatar---nagrada-simply-the-best, 143.html (Accessed 26 February 2015)

http://www.tzzz.hr/biciklisticke-karte/karta-3/ (Accessed 26 February 2015)

https://www.youtube.com/watch?v=7rJMILDMrJI (Accessed 26 February 2015).

http://www.zagreb-touristinfo.hr/istrazi-zagreb/zagreb-i-okolica/sjever (Accessed 26 February 2015) 
